\title{
Heat flow density estimates in the Upper Rhine Graben using laboratory measurements of thermal conductivity on sedimentary rocks
}

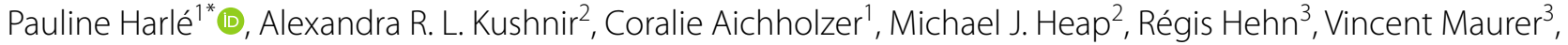 \\ Patrick Baud ${ }^{2}$, Alexandre Richard ${ }^{3}$, Albert Genter ${ }^{3}$ and Philippe Duringer ${ }^{1}$
}

\section{*Correspondence:}

p.harle@unistra.fr

${ }^{1}$ Institut de Physique du

Globe de Strasbourg (IPGS),

UMR 7516, CNRS-Université de Strasbourg EOST, 1 Rue

Blessig, 67084 Strasbourg

Cedex, France

Full list of author information is available at the end of the article

\begin{abstract}
The Upper Rhine Graben (URG) has been extensively studied for geothermal exploitation over the past decades. Yet, the thermal conductivity of the sedimentary cover is still poorly constrained, limiting our ability to provide robust heat flow density estimates. To improve our understanding of heat flow density in the URG, we present a new large thermal conductivity database for sedimentary rocks collected at outcrops in the area including measurements on (1) dry rocks at ambient temperature (dry); (2) dry rocks at high temperature (hot) and (3) water-saturated rocks at ambient temperature (wet). These measurements, covering the various lithologies composing the sedimentary sequence, are associated with equilibrium-temperature profiles measured in the Soultz-sous-Forêts wells and in the GRT-1 borehole (Rittershoffen) (all in France). Heat flow density values considering the various experimental thermal conductivity conditions were obtained for different depth intervals in the wells along with average values for the whole boreholes. The results agree with the previous heat flow density estimates based on dry rocks but more importantly highlight that accounting for the effect of temperature and water saturation of the formations is crucial to providing accurate heat flow density estimates in a sedimentary basin. For Soultz-sous-Forêts, we calculate average conductive heat flow density to be $127 \mathrm{~mW} / \mathrm{m}^{2}$ when considering hot rocks and $184 \mathrm{~mW} / \mathrm{m}^{2}$ for wet rocks. Heat flow density in the GRT-1 well is estimated at 109 and $164 \mathrm{~mW} / \mathrm{m}^{2}$ for hot and wet rocks, respectively. Results from the Rittershoffen well suggest that heat flow density is nearly constant with depth, contrary to the observations for the Soultz-sous-Forêts site. Our results show a positive heat flow density anomaly in the Jurassic formations, which could be explained by a combined effect of a higher radiogenic heat production in the Jurassic sediments and thermal disturbance caused by the presence of the major faults close to the Soultz-sous-Forêts geothermal site. Although additional data are required to improve these estimates and our understanding of the thermal processes, we consider the heat flow densities estimated herein as the most reliable currently available for the URG.
\end{abstract}

Keywords: Heat flow density, Upper Rhine Graben, Thermal conductivity, Saturation, Temperature, Sedimentary rocks, Geothermal energy, Soultz-sous-Forêts, Rittershoffen 


\section{Background}

The Upper Rhine Graben (URG) has been known to be a region of high heat flow density for more than 40 years (Cermák and Rybach 2012; Gable 1986; Lucazeau and Vasseur 1989; Rybach 2007; Vasseur 1980, 1982). This regional conductive heat flow density anomaly is due to crustal thinning caused by extension during the Cenozoic and facilitated by the basin-wide deep-rooted groundwater circulation that locally enhances the surface heat flow density (Clauser and Villinger 1990; Schellschmidt and Schulz 1992). Due to the heat flow density anomaly, the URG represents an ideal region for geothermal exploitation. Located in the northeastern part of France and southwestern part of Germany (Fig. 1), this continental rift is already home to several operational (e.g., Soultz-sous-Forêts and Rittershoffen, both France, and Bruchsal, Insheim and Landau, all in Germany) and planned (e.g., Illkirch, Vendenheim, and Wissembourg, all France) geothermal sites (Aichholzer et al. 2016; Vidal and Genter 2018), but accurate estimates of heat flow density remain crucial for temperature estimations prior to drilling operations and thermodynamic models that inform our understanding of measured temperature profiles for continued geothermal exploration (Beardsmore et al. 2001; Flores Marquez 1992; Frone et al. 2015; Schütz et al. 2014).

Thermal profiles of operational wells have revealed conductive heat flow density in the upper 1-1.5 km, as opposed to convective heat flow density common to the geothermal reservoir (Bächler et al. 2003; Baillieux et al. 2013; Clauser and Villinger 1990; Guillou-Frottier et al. 2013; Kohl et al. 2000; Le Carlier et al. 1994; Magnenet et al. 2014; Pribnow and Schellschmidt 2000). When conductive regime dominates in the Earth's crust, conductive heat flow density (also called surface or terrestrial heat flow density) is estimated using Fourier's law of heat conduction $q=\lambda \times\left(\frac{\Delta T}{\Delta z}\right)$, where $q$ is the conductive heat flow density $\left(\mathrm{W} / \mathrm{m}^{2}\right), \lambda$ is thermal conductivity $(\mathrm{W} / \mathrm{mK})$ and $\left(\frac{\Delta T}{\Delta z}\right)$ is the temperature gradient $\left({ }^{\circ} \mathrm{C} / \mathrm{m}\right.$ ) (Beardsmore et al. 2001). Conductive heat flow density can thus be defined as the product of the thermal gradient and the mean thermal conductivity of the medium. Thermal conductivity describes the capacity of a material to transfer heat in the presence of a thermal gradient and is a major parameter controlling the conductive heat flow density. The thermal conductivity of the rocks depends not only on mineralogical composition and microstructure (porosity, fracture density, texture), but also on pressure, rock temperature and degree of saturation and nature of the fluid. The effect of those parameters on thermal conductivity have been largely investigated by previous studies, which showed that the thermal conductivity of rocks generally decreases with increasing porosity (Woodside and Messmer 1961; Popov et al. 2003; Nagaraju and Roy 2014; Guo et al. 2017; Mielke et al. 2017), whereas pressure tends to reduce porosity, close (micro)cracks and improve heat transport at grain-grain contacts and, thus, increase thermal conductivity (Walsh and Decker 1966; Abdulagatova et al. 2009; Schön and Dasgupta 2015). On the contrary, high temperature tends to decrease the thermal conductivity of rocks due to differential thermal expansion of the minerals, which may increase contact resistances between the grains and result in thermal cracking creating porosity (Vosteen 
and Schellschmidt 2003; Abdulagatov et al. 2006; Abdulagatova et al. 2009; Guo et al. 2017). Finally, thermal conductivity increases with water saturation compared to dry conditions as water conducts heat much better than air (Zimmerman 1989; Popov et al. 2003; Schütz et al. 2012; Nagaraju and Roy 2014; Guo et al. 2017; Albert et al. 2017).

Thus, at prospective geothermal sites where conduction dominates heat transfer in the upper few kilometers of the crust, a combined understanding of the geology and the thermal conductivity of the rocks (preferably at the in situ temperature and fluid saturation conditions) can be used to provide useful conductive heat flow density estimates.

Studies have defined a mean conductive heat flow density between 100 and $120 \mathrm{~mW} /$ $\mathrm{m}^{2}$ in the URG, with a maximum value of $150 \mathrm{~mW} / \mathrm{m}^{2}$ at Soultz-sous-Forêts (Baillieux et al. 2013; Kohl et al. 2000), much higher than the mean value of $60 \mathrm{~mW} / \mathrm{m}^{2}$ in Europe (Majorowicz and Wybraniec 2011). Unfortunately, the absence of a large database for thermal conductivities of sedimentary rocks from the region implies that these heat flow density estimates are based on a limited number of thermal conductivity values, often determined for general lithologies that may not be fully representative of the formations within the graben (Flores Marquez 1992). This lack of data for the upper part of the sedimentary cover can lead to unreliable estimations of the local heat flow density (Fuchs and Balling 2016). Moreover, the thermal conductivity values considered for these early heat flow density estimations are for rocks in the dry state at ambient temperature and the absence of URG-specific models makes them difficult to port to in situ conditions. Indeed, while mixing models (Abdulagatova et al. 2009; Fuchs et al. 2013; Vosteen and Schellschmidt 2003) are valuable when no or very few samples from the study area are available, it is always preferable to gather a regional database when possible. Thus, new thermal conductivity measurements under various temperature and saturation conditions for a wide range of sedimentary formations from the URG are required to provide robust heat flow density estimates.

Although geothermal exploitation is well-developed in the URG, the thermal conductivity of the sedimentary cover is still poorly known, mostly due to the lack of core material, in particular in the upper strata (above the Muschelkalk series) where conduction predominates.

Here, we analyze the behavior of thermal conductivity of sedimentary rocks sampled in the URG as a function of different parameters including porosity, fluid saturation and temperature, with the aim of providing a new thermal conductivity database for the URG. This large database is used to provide more accurate heat flow density estimates for sites where an equilibrium-temperature profile is known. The influence of the various thermal conductivity measurement conditions on the calculated heat flow density is also investigated. Using these laboratory data, we estimate the heat flow density for the Soultz-sous-Forêts and Rittershoffen operational industrial wells.

\section{The geology of the Upper Rhine Graben (URG)}

To perform this study, we collected analogue rock samples that best represent the geological formations of the Upper Rhine Graben. 


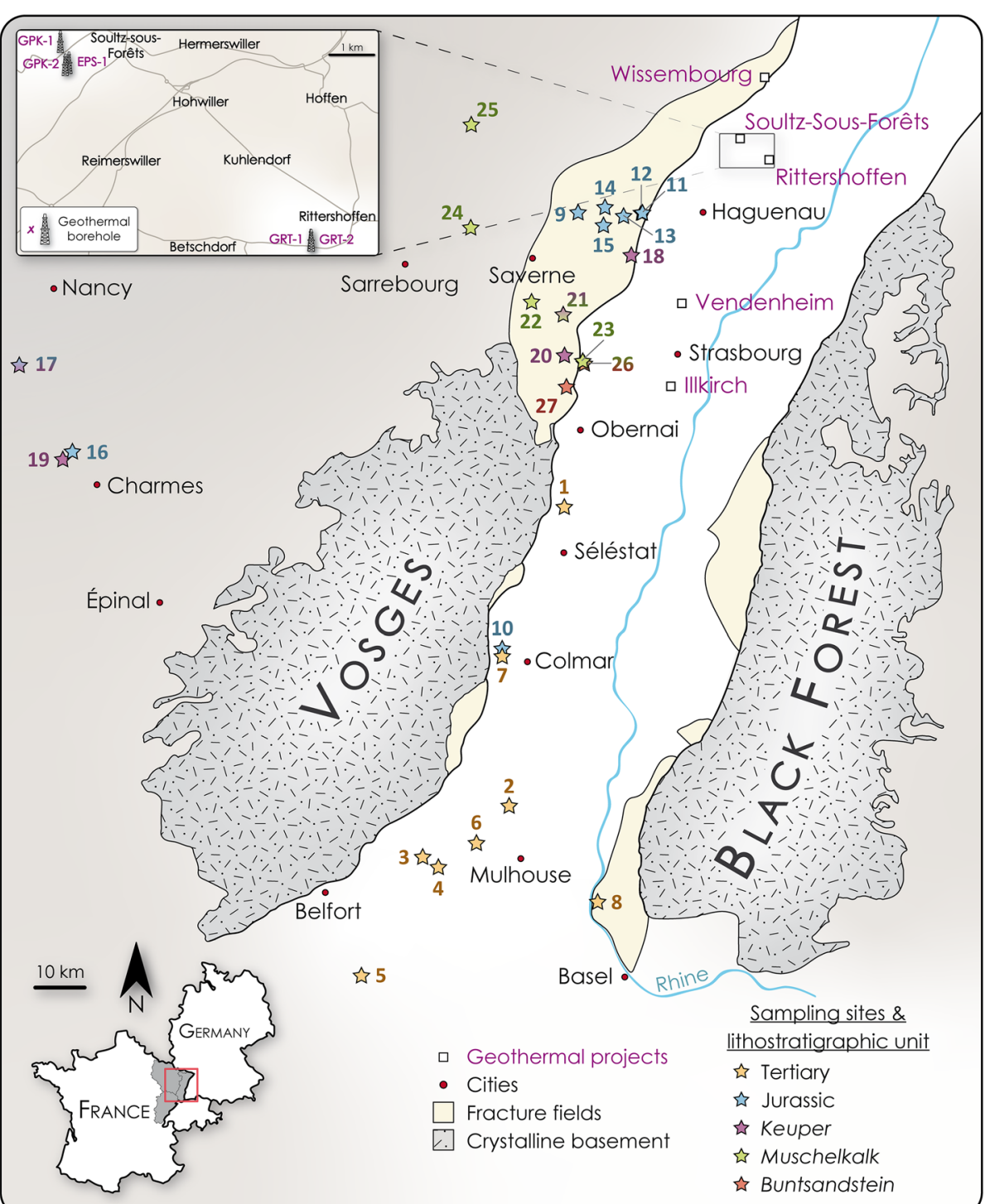

Fig. 1 Map of the Upper Rhine Graben showing the sampling sites and the existing and prospective geothermal projects. Numbered stars refer to sampling locations, given in Figs. 2 and 3. The color of the stars indicates the lithostratigraphic unit. More than one lithostratigraphic unit was sampled in locations 17, 21 and 26 (modified after Aichholzer et al. (2016))

In this study, "facies" refers to the lithology (rock type), sedimentary structures and depositional environments characterizing the rock. "Sedimentary formation" refers to a set of homogenous sedimentary strata with the same facies and paleontological content and characterized by obvious lower and upper boundaries. A "series" of formations, like the Muschelkalk or the Buntsandstein series, refers to a group of sedimentary formations deposited within the same geodynamic context, for example in fluvial systems for the Buntsandstein.

In the URG, the deep Paleozoic basement is covered by Permian clastic formations. Above these Permian sedimentary rocks are the fluvial to fluvio-deltaic sandstones and conglomerates of the lower Triassic Buntsandstein (B) series, overlain by 
marine-to-lagoonal sediments of the middle Triassic Muschelkalk (M) series (Aichholzer et al. 2016). The Muschelkalk formations are mainly composed of interbedded marlycalcareous rocks, shelly sandstones, evaporitic deposits, and dolostones (Duringer et al. 2019; Ménillet 2015). The carbonate-shelf environment that formed the upper Muschelkalk series was followed by the evaporitic episode of the Keuper (K), upper Triassic. The Keuper is characterized by massive clays, marly clays and dolomites that contain evaporitic deposits (gypsum and anhydrite). Some sandstone marker beds are also encountered in the lower, middle and upper Keuper formations (Aichholzer et al. 2016; Duringer et al. 2019; Ménillet 2015). The depositional environment became fully marine from the Jurassic, with marls/limestones alternations during Hettangian, followed by clays and clayey marls alternations with occasional calcareous banks up to the base of Bajocian. Bajocian was characterized by carbonate-shelf episodes (Duringer et al. 2019; Ménillet 2015). The sedimentary formations described above were deposited before the rift episode of the graben and can be found beyond the borders of the URG.

The Tertiary rocks were unconformingly deposited on top of the eroded upper Jurassic sediments (Berger et al. 2005; Duringer et al. 2019; Hinsken et al. 2007, 2011; Roussé 2006; Sittler 1965, 1992). Eocene and lower Oligocene formations are composed, from base to top, by lacustrine and evaporitic clays, marls, limestones and a few sandstones in the central part of the graben and conglomerates on the borders (Zone Dolomitique, Couche Rouge and Couches de Pechelbronn in the North and Zone Salifère inférieure, moyenne and supérieure in the South (see Duringer et al. 2019). Middle and upper Oligocene deposits are formed by marine clays and marls intercepted by some poorly cemented sandstones (Série Grise). The retreat of the sea in the graben at the end of the Rupelian (upper Oligocene) led to the deposition of the thick formation of the Couches de Niederroedern also called Série Bariolée. This formation is a lacustrine-to-fluvial variegated marly formation attributed to the Chattian (Berger et al. 2005; Hinsken et al. 2007, 2011; Roussé 2006; Sittler 1965). The upper Oligocene is eroded in some parts of the rift and the Miocene does not exist in the whole graben due to erosion (Aichholzer et al. 2016; Berger et al. 2005; Roussé 2006). The uppermost part of the sedimentary cover is characterized by a continental episode made of fluvial to ephemeral lake deposits that were formed during the Pliocene. Loess deposited during the Quaternary ends the sedimentary cover (Duringer et al. 2019; Ménillet 2015).

\section{Case study: the Soultz-sous-Forêts geothermal site}

Started in the 1980s, the Soultz-sous-Forêts (northern Alsace, France) (Fig. 1) project was the first Enhanced Geothermal System (EGS) developed in the world (Baria et al. 1999; Genter et al. 2010; Gérard et al. 2006; Kappelmeyer 1991). The geology at the Soultz-sous-Forêts site is well known thanks to an old exploratory oil borehole, EPS1, that was deepened for the needs of geothermal exploration and fully cored from 933 (middle Muschelkalk) to 2227 m (Paleozoic basement) (Aichholzer et al. 2019; Dezayes et al. 2005) e.g., in the zone where convection predominates (Genter and Traineau 1992). The Permian and Triassic sedimentary rocks of the Buntsandstein are described in Aichholzer et al. $(2016,2019)$ and Vidal et al. (2015) and physical properties of the EPS-1 cores studied by Géraud et al. (2010), Griffiths et al. (2016), Haffen (2012), Haffen et al. (2013, 2017), Heap et al. (2017, 2018, 2019), Kushnir et al. (2018), Surma and Geraud 
(2003), Schellschmidt and Clauser (1996), Flores Marquez 1992 and Schellschmidt and Schulz (1992).

In total, four boreholes have been drilled at the Soultz-sous-Forêts site: GPK-1, GPK-2, GPK-3, and GPK-4, the last three of which extend to a depth of $5 \mathrm{~km}$. The stratigraphy of the GPK-1 and 2 boreholes was described in detail by Aichholzer et al. (2016) and is composed of $1400 \mathrm{~m}$ (measured depth, MD) of sedimentary cover. These boreholes have provided precious data including temperature profiles that inform on regional heat transfer mechanisms (conduction and convection). At Soultz-sous-Forêts, the typical equilibrium-temperature profiles measured in the $5-\mathrm{km}$-deep wells revealed a temperature of $200{ }^{\circ} \mathrm{C}$ at a depth of $5 \mathrm{~km}$. Importantly, the temperature profile can be divided into three parts (Genter et al. 2010, 2015; Vidal et al. 2015). First, the uppermost part of the well (between 0 and $1 \mathrm{~km}$-depth, down to the top of the Muschelkalk series), composed of sedimentary formations (Tertiary, Jurassic, and Upper Triassic), features a geothermal gradient of $110{ }^{\circ} \mathrm{C} / \mathrm{km}$, which, in the URG, indicates a conductive regime (Pribnow and Schellschmidt 2000). The section between a depth of 1 and $3.5 \mathrm{~km}$, comprising the sedimentary rocks of the Buntsandstein series (down to a depth of about $1400 \mathrm{~m}$ ) and fractured granitic basement, is characterized by a very low thermal gradient of $5{ }^{\circ} \mathrm{C} / \mathrm{km}$, interpreted as convective regime in the URG. Finally, the deepest part of the thermal profile, below a depth of $3.5 \mathrm{~km}$, is composed exclusively of crystalline basement and features a thermal gradient of $30{ }^{\circ} \mathrm{C} / \mathrm{km}$, indicating another conduction zone. At the Soultz-sous-Forêts site, the previously estimated heat flow densities range between 140 and $150 \mathrm{~mW} / \mathrm{m}^{2}$ (Baillieux et al. 2013; Flores Marquez 1992; Pribnow and Clauser 2000; Le Carlier et al. 1994; Schellschmidt and Clauser 1996).

\section{Case study: the Rittershoffen geothermal site (France)}

The Rittershoffen geothermal site, located 6 km southeast of Soultz-sous-Forêts (Fig. 1), is the second EGS project developed in northern Alsace (Baujard et al. 2017). To date, no heat flow density has been calculated for the Rittershoffen geothermal site. However, a heat flow density of $121 \mathrm{~mW} / \mathrm{m}^{2}$ has been calculated for a nearby borehole (SAN 1 (SANDMUHLE 1) borehole, about $3.5 \mathrm{~km}$ from the GRT-1 well) (Lucazeau 2019). The drilled GRT-1 and GRT-2 boreholes extend to a depth of 2580 and 3196 m MD, respectively, and target the geothermal reservoir located at the sediment-basement interface. Temperature measurements in the wells indicate a constant thermal gradient of $87^{\circ} \mathrm{C} / \mathrm{km}$ (conduction) in the sedimentary cover between the surface and the top of the Muschelkalk (1661 m depth MD), and an average temperature of $160{ }^{\circ} \mathrm{C}$ at the top of the Muschelkalk cap rock (Baujard et al. 2017). The very low gradient $\left(3^{\circ} \mathrm{C} / \mathrm{km}\right)$ below this depth threshold indicates a convective regime in the Muschelkalk and Buntsandstein sedimentary formations, and in the fractured granitic basement.

Stratigraphy of the 2200-m-thick sedimentary cover in GRT-1 has been recently updated by Duringer et al. (2019) and correlated with stratigraphy in GPK-1 and GPK-2 in Aichholzer et al. (2016), which revealed several variations in the sedimentary cover between the two sites and even between the two wells at Soultz-sous-Forêts. Differences include missing layers due to erosion, lateral thickness variations in sedimentary formations and thinning or absence of some formations due to faulting. 


\section{Methods}

\section{Selecting representative rock samples}

We collected 45 samples (typically $15 \times 15 \times 15 \mathrm{~cm}$ ) from 27 different locations in the east of France (Alsace, Lorraine and Franche-Comté) and in Southwest Germany (Baden-Württemberg) (Figs. 1, 2, 3) that we consider provide a representative suite of rocks for the sedimentary cover of the URG. The choice of samples collected was guided by the formations encountered in the wells at Rittershoffen (Duringer et al. 2019) and the wells at Soultz-sous-Forêts (Aichholzer et al. 2016). But for completeness, we sampled additional formations that are widespread in the region including, for instance, the Grande Oolithe [J-GO (Fig. 2)] formation, which is absent in the northern part of the URG due to erosion, but encountered to the south of Haguenau. We did not only sample the thickest formations, but also formations that represent outliers, in terms of lithology and texture, that may be characterized by very different thermal conductivities. Most samples were collected from rock outcrops, those not available at outcrops were collected at the potash mines in Wittelsheim (France) (O-ZSS samples) or sourced from drill cores from the DP202 borehole in Pulversheim (France) (O-CN and O-CM samples). We note that poorly consolidated formations were not sampled because it was not possible to prepare a sample suitable for measurement in the laboratory. The sampled

\begin{tabular}{|c|c|c|c|c|c|c|c|c|}
\hline & STRATI & GRAPHY & & $\begin{array}{l}\text { SAMPLING } \\
\text { SITE } \mathbf{N}^{\circ}\end{array}$ & SAMPLE & STRATIGRAPHIC UNIT & $\begin{array}{l}\text { NATURE OF THE } \\
\text { SAMPLED ROCK }\end{array}$ & $\begin{array}{l}\text { LOCATION OF THE } \\
\text { SAMPLING SITE }\end{array}$ \\
\hline \multirow{8}{*}{ 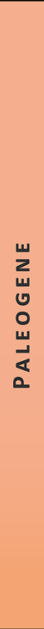 } & \multirow{6}{*}{$\begin{array}{l}u \\
z \\
u \\
u \\
0 \\
v \\
\overrightarrow{0} \\
0\end{array}$} & Chattian & 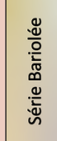 & $\begin{array}{l}1 \\
1 \\
1 \\
2\end{array}$ & $\begin{array}{c}\text { O-CNgs } \\
\text { O-CNm-gv } \\
\text { O-CNm-j } \\
\text { O-CNm_Core }\end{array}$ & $\begin{array}{l}\text { Couches de Niederroedern } \\
\text { Couches de Niederroedern } \\
\text { Couches de Niederroedern } \\
\text { Couches de Niederroedern }\end{array}$ & $\begin{array}{l}\text { Friable sandstone } \\
\qquad \begin{array}{l}\text { Marls } \\
\text { Marls } \\
\text { Marls }\end{array}\end{array}$ & $\begin{array}{c}\text { Blettig Epfig } \\
\text { Blettig Epfig } \\
\text { Blettig Epfig } \\
\text { Pulversheim - DP202 Borehole }\end{array}$ \\
\hline & & \multirow{5}{*}{ 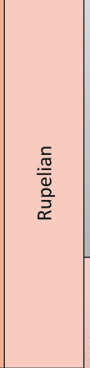 } & \multirow{3}{*}{ 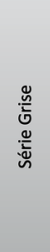 } & $\begin{array}{l}3 \\
3 \\
3\end{array}$ & $\begin{array}{l}\text { O-MCm } \\
\text { O-MCg-f } \\
\text { O-MCg-d }\end{array}$ & $\begin{array}{l}\text { Marnes à Cyrènes } \\
\text { Marnes à Cyrènes } \\
\text { Marnes à Cyrènes }\end{array}$ & $\begin{array}{c}\text { Marls } \\
\text { Friable sandstone } \\
\text { Consolidated sandstone }\end{array}$ & $\begin{array}{l}\text { Guewenheim } \\
\text { Guewenheim } \\
\text { Guewenheim }\end{array}$ \\
\hline & & & & $\begin{array}{l}4 \\
4 \\
2\end{array}$ & $\begin{array}{c}\text { O-CMm } \\
\text { O-CMg } \\
\text { O-CMm_Core }\end{array}$ & $\begin{array}{l}\text { Couches à Mélettes } \\
\text { Couches à Mélettes } \\
\text { Couches à Mélettes }\end{array}$ & $\begin{array}{l}\text { Marls } \\
\text { Sandstone } \\
\text { Marls }\end{array}$ & $\begin{array}{l}\text { Burnhaupt le Haut } \\
\text { Burnhaupt le Haut } \\
\text { Pulversheim - DP202 Borehole }\end{array}$ \\
\hline & & & & 5 & O-SP & Schistes à Poissons & Marls & Froidefontaine \\
\hline & & & \multirow{3}{*}{ 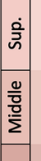 } & $\begin{array}{l}6 \\
6\end{array}$ & $\begin{array}{l}\text { o-zsScm } \\
\text { o-ZsSpo }\end{array}$ & $\begin{array}{l}\text { Zone Salifère sup. } \\
\text { Zone Salifère sup. }\end{array}$ & $\begin{array}{l}\text { Marly limestone } \\
\text { Potash }\end{array}$ & $\begin{array}{l}\text { MDPA - Wittelsheim } \\
\text { MDPA - Wittelsheim }\end{array}$ \\
\hline & & & & 7 & O-ZFm & Zone Fossilifère & Marls & Turckheim \\
\hline & \multirow{2}{*}{$\begin{array}{l}\text { ü } \\
\ddot{u} \\
\text { o } \\
\text { w }\end{array}$} & Priabonian & & 7 & E-ZSMm & Zone Salifère moy. & Marls & Turckheim \\
\hline & & Bartonian & $\stackrel{N}{\underline{E}}$ & $\begin{array}{l}8 \\
8\end{array}$ & $\begin{array}{l}E-Z S I g \\
E-Z S I m\end{array}$ & $\begin{array}{l}\text { Zone Salifère inf. } \\
\text { Zone Salifère inf. }\end{array}$ & $\begin{array}{c}\text { Calcareous sandstone } \\
\text { Marls }\end{array}$ & $\begin{array}{l}\text { Kleinkems } \\
\text { Kleinkems }\end{array}$ \\
\hline \multirow{7}{*}{ 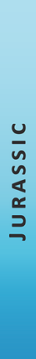 } & \multirow{5}{*}{ 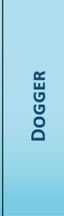 } & \multirow{4}{*}{\multicolumn{2}{|c|}{ Bajocian }} & 9 & J-GO & Grande Oolithe & Oolithic limestone & Bouxwiller \\
\hline & & & & $\begin{array}{l}10 \\
11\end{array}$ & $\begin{array}{l}\text { J-GO_Col } \\
\text { J-CAC }\end{array}$ & $\begin{array}{l}\text { Grande Oolithe } \\
\text { Couches à Acuminata }\end{array}$ & $\begin{array}{l}\text { Oolithic limestone } \\
\text { Shelly limestone }\end{array}$ & $\begin{array}{l}\text { Ingersheim } \\
\text { Morschwiller }\end{array}$ \\
\hline & & & & 12 & J-CE & Calcaire d'Ettendorf & Shelly limestone & Morschwiller \\
\hline & & & & 13 & J-MCEC & Marnes et Calcaires d'Ettendorf & Limestone & Ettendorf \\
\hline & & \multicolumn{2}{|c|}{ Aalenian } & 14 & J-FSg & Formation de Schalkendorf & Calcareous sandstone & Buswiller \\
\hline & \multirow{2}{*}{$\underline{y}$} & \multicolumn{2}{|c|}{ Pliensbachian } & $\begin{array}{l}15 \\
15\end{array}$ & $\begin{array}{l}\text { J-CK } \\
\text { J-MO }\end{array}$ & $\begin{array}{l}\text { Calcaire de Kirrwiller } \\
\text { Marnes à Ovoïdes }\end{array}$ & $\begin{array}{l}\text { Shelly limestone } \\
\text { Marls }\end{array}$ & $\begin{array}{l}\text { Lixhausen } \\
\text { Lixhausen }\end{array}$ \\
\hline & & \multicolumn{2}{|c|}{$\begin{array}{l}\text { Sinemurian } \\
\text { Hettangian }\end{array}$} & $\begin{array}{l}16 \\
17\end{array}$ & $\begin{array}{l}\text { J-CMGC } \\
\text { J-CMGm }\end{array}$ & $\begin{array}{l}\text { Calcaires et Marnes à Gryphées } \\
\text { Calcaires et Marnes à Gryphées }\end{array}$ & $\begin{array}{l}\text { Limestone } \\
\text { Marls }\end{array}$ & $\begin{array}{l}\text { Lebeuville } \\
\text { Xeuilley }\end{array}$ \\
\hline
\end{tabular}

Fig. 2 List of Tertiary and Jurassic samples classed in stratigraphic order. Lithostratigraphic unit, number of the sampling site (see Fig. 1 for location on the map), nature of the sampled rock and location of the sampling site are indicated 


\begin{tabular}{|c|c|c|c|c|c|c|c|c|c|}
\hline & \multicolumn{4}{|c|}{ STRATIGRAPHY } & \multirow{2}{*}{$\begin{array}{c}\text { SAMPLING } \\
\text { SITE } \mathbf{N}^{\circ} \\
17\end{array}$} & \multirow{2}{*}{$\begin{array}{c}\text { SAMPLE } \\
\text { K-ALEV }\end{array}$} & \multirow{2}{*}{$\begin{array}{c}\text { STRATIGRAPHIC UNIT } \\
\text { Argiles de Levallois }\end{array}$} & \multirow{2}{*}{$\begin{array}{l}\text { NATURE OF THE } \\
\text { SAMPLED ROCK }\end{array}$} & \multirow{2}{*}{$\begin{array}{c}\text { LOCATION OF THE } \\
\text { SAMPLING SITE } \\
\text { Xeuilley }\end{array}$} \\
\hline & \multirow{9}{*}{\multicolumn{2}{|c|}{ : }} & $\frac{\dot{2}}{3}$ & Rhaetian & & & & & \\
\hline & & & \multirow{6}{*}{$\frac{0}{\frac{0}{z}}$} & \multirow{3}{*}{ Norian } & 18 & K-MISm & Marnes Irisées supérieures & Dolomitic marls & Waltenheim-sur-Zorn \\
\hline & & \multirow{7}{*}{ 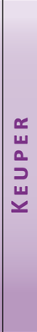 } & & & 18 & K-MISgy & Marnes irisées supérieures & Sucrosic gypsum & Waltenheim-sur-Zorn \\
\hline & & & & & 18 & K-MISd & Marnes Irisées supérieures & Dolostone & Waltenheim-sur-Zorn \\
\hline & & & & \multirow{3}{*}{ Carnian } & 19 & $K-D B$ & Dolomie de Beaumont & Dolostone & Xirocourt \\
\hline & & & & & 20 & $K-G R$ & Grès à Roseaux & Sandstone & Balbronn \\
\hline & & & & & 20 & K-MIgV & Marnes Irisées inférieures & Fibrous gypsum & Balbronn \\
\hline \multirow{11}{*}{$\begin{array}{l}u \\
u \\
n \\
u \\
\frac{a}{c} \\
r\end{array}$} & & & ऐँ & \multirow{4}{*}{ Ladinian } & 21 & K-Dld & Dolomie Inférieure & Dolostone & Wasselone \\
\hline & & & 오 & & 21 & K-DIm & Dolomie Inférieure & Marls & Wasselone \\
\hline & \multirow{7}{*}{$\frac{\frac{0}{0}}{\frac{0}{2}}$} & \multirow{7}{*}{ 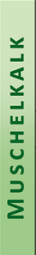 } & \multirow{3}{*}{ 产 } & & 21 & $\mathrm{M}-\mathrm{CCC}$ & Couches à Cératites & Limestone & Wasselone \\
\hline & & & & & 21 & $\mathrm{M}-\mathrm{CCm}$ & Couches à Cératites & Marls & Wasselone \\
\hline & & & & \multirow{7}{*}{ Anisian } & 22 & $\mathrm{M}-\mathrm{CE}$ & Calcaire à Entroques & Crinoidal limestone & Dimbsthal \\
\hline & & & $\dot{\vec{\delta}}$ & & 23 & $M-D L$ & Dolomie à Lingules & Dolostone & Soultz-les-Bains \\
\hline & & & & & 24 & $\mathrm{M}-\mathrm{CO}$ & Calcaires Ondulés & Limestone & Vescheim \\
\hline & & & ऐo & & 25 & $\mathrm{M}-\mathrm{CM}$ & Couches à Myacites & Marls & Lorentzen \\
\hline & & & & & 26 & $M-G C$ & Grès Coquillier & Shelly sandstone & Soultz-les-Bains \\
\hline & \multirow{2}{*}{$\begin{array}{l}1 \\
0 \\
3 \\
0 \\
\end{array}$} & \multirow{2}{*}{ 占 } & \multirow{2}{*}{$\begin{array}{l}\text { ळे } \\
\text { 음 }\end{array}$} & & 26 & $B-G V$ & Grès ù Voltzia & Clayey sandstone & Soultz-les-Bains \\
\hline & & & & & 27 & $\mathrm{~B}-\mathrm{Cl}$ & Couches Intermédiaires & Sandstone & Mutzig \\
\hline
\end{tabular}

Fig. 3 List of Keuper, Muschelkalk and Buntsandstein samples classed in stratigraphic order. Lithostratigraphic unit, number of the sampling site (see Fig. 1 for location on the map), nature of the sampled rock and location of the sampling site are indicated

formations that most closely represent those that could not be sampled were used as proxies.

Our method to estimate heat flow density is designed to be used at prospective geothermal sites for which there are no boreholes, therefore, in the absence of site-specific rock samples. Although measurements on analogue samples should be used with care (Bauer et al. 2017), we have chosen to measure samples taken from rock outcrops for several reasons. First, when boreholes do exist (such as at Soultz-sous-Forêts and Rittershoffen), the recovered rock cuttings are often too small to make reliable laboratory measurements. Further, despite having cores from exploration well EPS-1 (at the Soultzsous-Forêts site), these cores are only available from a depth of $933 \mathrm{~m}$ and therefore do not sample the conduction zone. Finally, not all regionally significant formations are encountered in the boreholes at Rittershoffen and Soultz-sous-Forêts (e.g., such as the Grande Oolithe, J-GO). Therefore, the accurate estimation of heat flow density is reliant on the establishment of a comprehensive thermal conductivity database developed using analogue geological materials that are representative of the local and regional geology, including outcrop material.

\section{Sample preparation}

Each rock sample was cut and polished to obtain two planer and parallel surfaces (Fig. 4a). When possible, two pieces of sample for each studied formation were prepared. The thickness of the prepared samples was typically between 2.5 and $4 \mathrm{~cm}$ to allow a probing depth sufficient for the measurement and so that the samples could fit in the experimental jig (Fig. 4b, c). As a precaution, samples considered sensitive to water, such as the potash and marls, were cut and polished without using water to minimize watermineral reactions that could affect the physical state of the samples. 


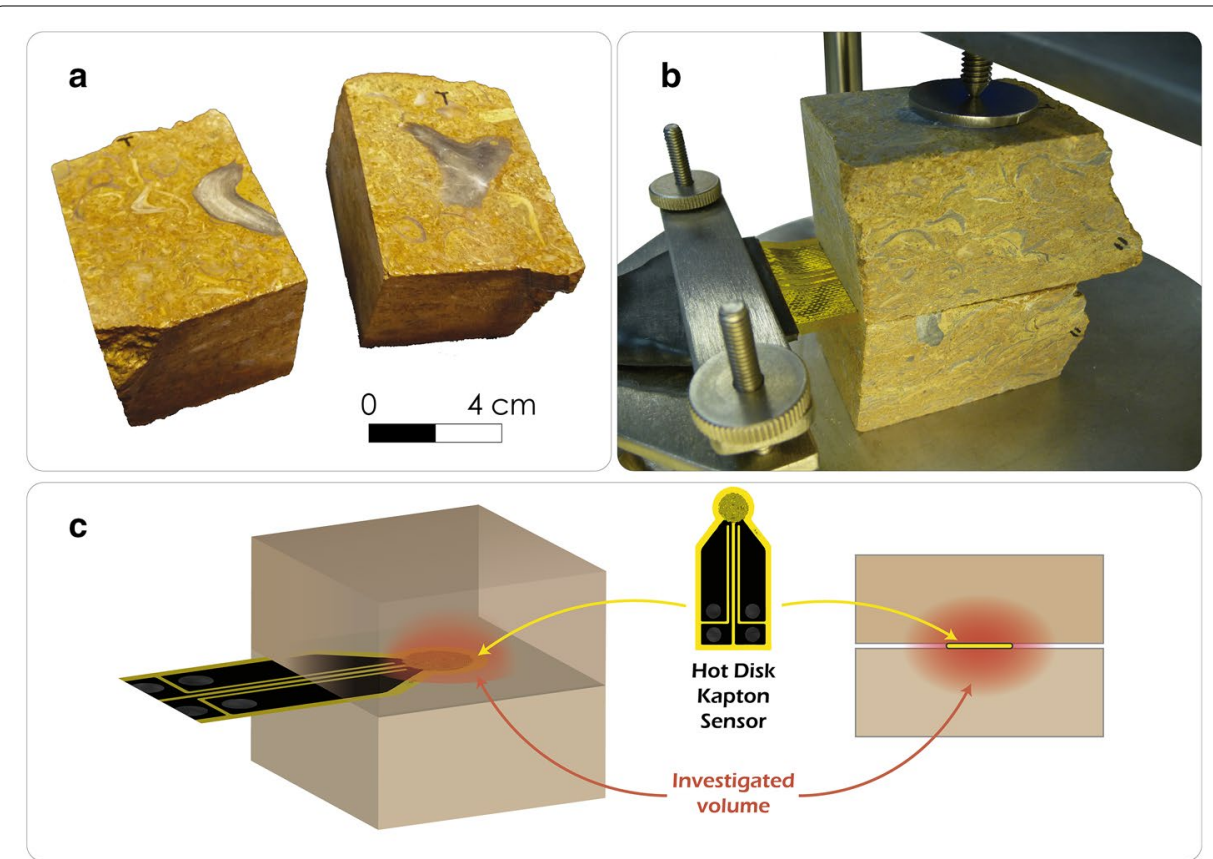

Fig. 4 a Example of a sample prepared for thermal conductivity measurements (sample J-CE; Calcaire $d^{\prime}$ Ettendorf). The samples were cut and polished to produce at least two planar and parallel surfaces. $\mathbf{b}$ Double-sided thermal conductivity measurement on J-CE sample in the dry state at ambient temperature. The two pieces of sample are placed either side of the sensor. The pieces are clamped together, to ensure a good contact between the pieces of sample and the sensor, using a metal screw at the top of the jig. $\mathbf{c}$ Schematic showing the setup and the volume around the sensor (probing depth) investigated during the measurement

Before characterization, all samples were vacuum-dried at $40^{\circ} \mathrm{C}$ overnight.

\section{Porosity measurements}

The connected porosity of the samples was measured to inform on the relationship between thermal conductivity and porosity. We used the triple-weight water saturation method (Guéguen and Palciauskas 1992). The dry samples were vacuum-saturated with water and the saturated mass $\left(m_{w}\right)$ and the immersed saturated mass $\left(m_{i}\right)$ of the samples were measured. The samples were then vacuum-dried again and the dry mass $\left(m_{d}\right)$ of each sample was measured. The connected water porosity, $\phi$, was calculated using the following equation (units: unitless, value given as \%):

$$
\phi=\frac{m_{w}-m_{d}}{m_{w}-m_{i}} .
$$

The porosities of the gypsum and the marl samples were not assessed for the samples on which thermal conductivity measurements were made; a separate sample set was dedicated to porosity measurements for these rocks. Although the thermal conductivities of these samples were measured in the wet condition (explained below), we wanted to avoid wet-dry cycles that may have influenced the physical state of these samples prior to measuring their thermal conductivity. The porosity of the potash samples could not be measured due to their dissolution upon exposure to water. 


\section{Thermal conductivity measurements}

The thermal conductivity measurements were conducted in the laboratory using a thermal analyzer (model TPS 500 by Hot Disk) based on the Transient Plane Source (TPS) method with a Kapton-plastic coated sensor (Gustafsson 1991; Gustavsson and Gustafsson 2005).

All the measurements were carried out at ambient pressure. The measurements were first conducted on oven-dry samples at room temperature ("dry"), then on water-saturated samples at room temperature ("wet") and, finally, on oven-dry samples at high temperature ("hot"; up to $160^{\circ} \mathrm{C}$ ). Samples could not be measured in the saturated state at high temperature nor at higher pressure conditions due to equipment constraints. The dry, wet, and hot measurements were all carried out on the same suite of rock samples. Whenever bedding was visible, the measurements were conducted such that the bedding was parallel to the sensor. Anisotropy of the samples could not be studied since the thermal analyzer used for the measurements averages the thermal properties of the investigated volume of rock.

\section{Dry measurements}

The dry measurements were carried out first because they are quick to perform and there is no risk of damaging the rock samples. To perform a measurement, the prepared, planer surfaces of two pieces of rock sample were placed either side of the sensor and the samples clamped together using a metal screw at the top of the jig, ensuring that the sample surfaces were flush with the sensor (Fig. 4b, c). During the measurement, an electrical current was passed through the sensor for a specified duration to increase sample temperature; the sensor recorded the temperature increase of the sample as a function of time. The Hot Disk software used these data to determine the thermal conductivity and thermal diffusivity (the specific heat capacity was calculated using these measured data). The temperature of the sample before the measurement (monitored using a hand-held thermometer) was also used in the calculation performed by the software. The measurement parameters (output power and measurement duration) depended on the thermal properties of the sample. For our measurements, we used output powers between 35 and $440 \mathrm{~mW}$ and measurement durations between 2.5 and $40 \mathrm{~s}$. We performed four measurements on each set of samples using the four permutations of sample configuration (since each sample has two plane parallel faces). The measurements were performed at least 5 min apart and once the sample had cooled back to room temperature following each measurement. For some formations, only one piece of sample could be prepared. To measure these samples, we used a piece of insulating foam of known thermal properties in place of the second piece of sample; the foam has a thermal conductivity, measured using the Hot Disk Analyzer, at least 10 times lower than that of the measured sample.

\section{Wet measurements}

We performed wet measurements on at least two samples per lithology (limestone, sandstone, dolostone, gypsum, and marl). The first sample was the sample closest to the mean dry thermal conductivity for that lithology. The second was the sample with either the lowest or highest dry thermal conductivity for a given lithology, depending on the 
distribution of dry conductivity for that lithology. Wet measurements on the marls could only be conducted on the K-MISm marls from the Marnes Irisées supérieures (K-MIS; Keuper) formation (Fig. 3), which remained coherent following saturation with water. The wet measurements were performed on samples vacuum-saturated with water using the same Hot Disk method described above. To ensure the samples remained water-saturated during the measurement, the entire sample jig was submerged in a water-filled container. Once the measurements were complete, the samples were air-dried and then vacuum-dried in an oven at $40{ }^{\circ} \mathrm{C}$, as described above.

\section{Hot measurements}

The hot measurements were performed last in case exposure to high temperature resulted in any changes to the rock microstructure (such as thermal microcracking) or mineral assemblage (e.g., the dehydroxylation of clays). Although the marls and gypsums may have been affected by exposure to water during the wet measurements, we decided to perform the measurements in the same order for consistency. Hot measurements were performed on the same samples as used for the wet measurements. Additionally, the thermal conductivities of the O-ZSSpo potash and the J-MO (Fig. 2) marls, which could not be measured wet, were measured at high temperature. The hot measurements were performed at temperatures between 50 and $160{ }^{\circ} \mathrm{C}$ (Additional file 1). The hot measurements were performed on oven-dry samples using the same Hot Disk method described above (using a sensor designed to withstand high temperatures). To perform the measurements, the entire sample jig was placed inside an oven. The temperature was then increased at a heating rate of $5{ }^{\circ} \mathrm{C} / \mathrm{min}$ until the target temperature was reached. After the oven had reached the programmed temperature, the stability of the sample temperature was monitored using the dedicated function of the Hot Disk and the measurements were only performed once the sample was at thermal equilibrium with temperature in the oven. A waiting time of at least $30 \mathrm{~min}$ between two consecutive measurements was used for the hot measurements.

The chosen target temperatures for each lithology depended on the temperature expected for that lithology in the subsurface and based on temperatures measured in the GPK-2 (Soultz-sous-Forêts) (Genter et al. 2010) and GRT-1 (Rittershoffen) wells (Baujard et al. 2017). For the formations not encountered in these wells, such as the Grande Oolithe (J-GO), the target temperatures were chosen based on the likely temperatures at the expected depths for these formations.

\section{Thermal conductivity results}

The measured thermal conductivities ("dry" for all samples and "wet" and "hot" for select samples) and connected porosities are given in Additional file 1. The connected porosity of our samples varies between 5 and $18 \%$ for the dolostones, between 0.5 and $22 \%$ for the limestones, between 2 and $36 \%$ for the sandstones, between 14 and $44 \%$ for the marls, and between 1 and $4 \%$ for the gypsum (Additional file 1; Fig. 5).

Thermal diffusivity and heat capacity of the samples are given in Additional file 1, but will not be discussed in this study. 


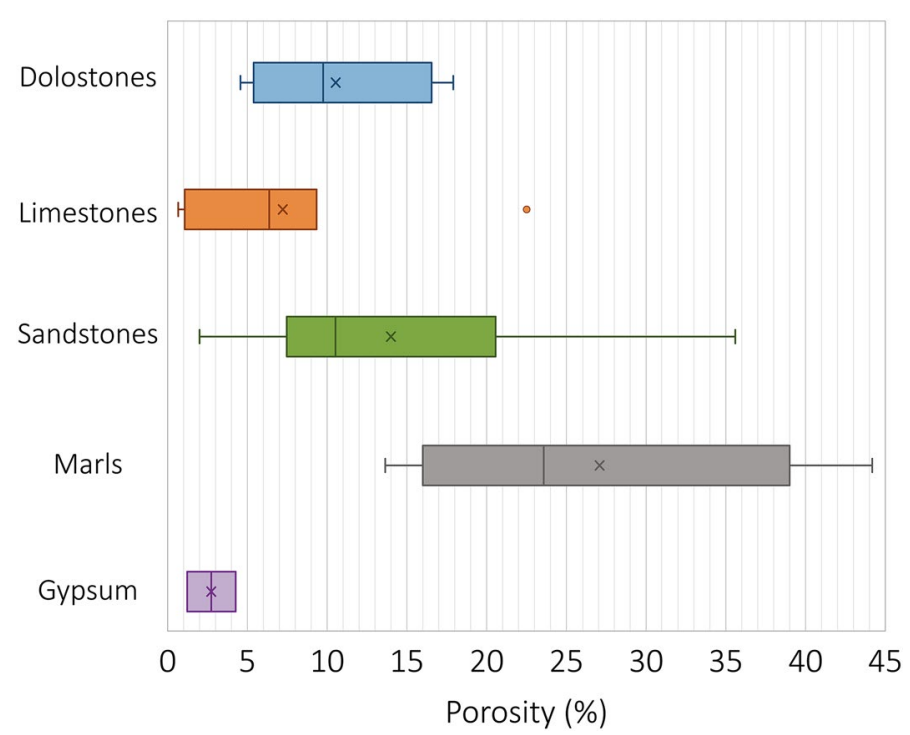

Fig. 5 Box and whisker plots of porosity ranges measured for the various lithologies

\section{Dry-state samples at ambient temperature}

Dry thermal conductivity is plotted as a function of porosity in Fig. 6. This figure shows that dry thermal conductivity decreases as porosity is increased. In our dataset, the range of thermal conductivity for a given porosity increased as porosity decreased. Despite the trend of decreasing thermal conductivity with increasing porosity, thermal conductivity also varies as a function of lithology. For example, the thermal conductivities of sandstone, limestone, and gypsum of similar porosities $(\phi \sim 2 \%)$ are $\sim 4, \sim 2.5$ to 3 , and $\sim 1.5 \mathrm{~W} / \mathrm{mK}$, respectively. For the low-porosity samples $(<20 \%)$, our results suggest

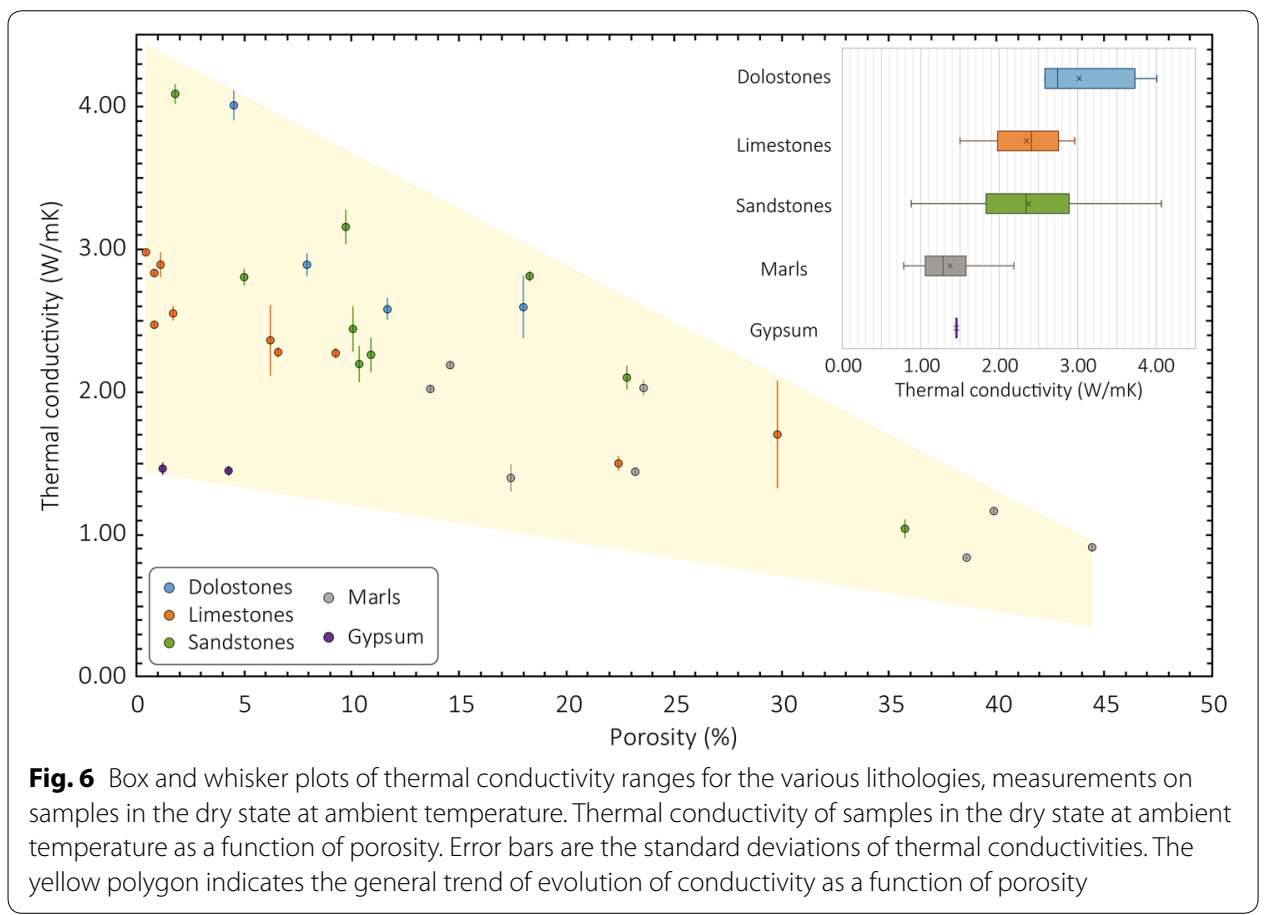


that the dolostones show the highest thermal conductivities, followed by the sandstones, the limestones and marls, and finally the gypsums. The dry thermal conductivity of the potash from the O-ZSS formation (not shown in Fig. 6) is $5.25 \mathrm{~W} / \mathrm{mK}$ (Additional file 1), the highest dry thermal conductivity of the entire sample suite.

\section{Wet-state samples at ambient temperature}

The wet thermal conductivities of the samples are compared with their corresponding dry thermal conductivities in Fig. 7a. The latter shows that the wet thermal conductivities of our sample suite are higher than their dry thermal conductivities for all but four of the samples. Only four samples (the M-GC shelly sandstone, the J-FSg calcareous sandstone, the limestone from the J-CE formation and the K-MISgy gypsum), which have low $(\phi<10 \%)$ porosities, have thermal conductivities higher in the dry state than in the saturated state (Fig. 7a). We examine the variation in thermal
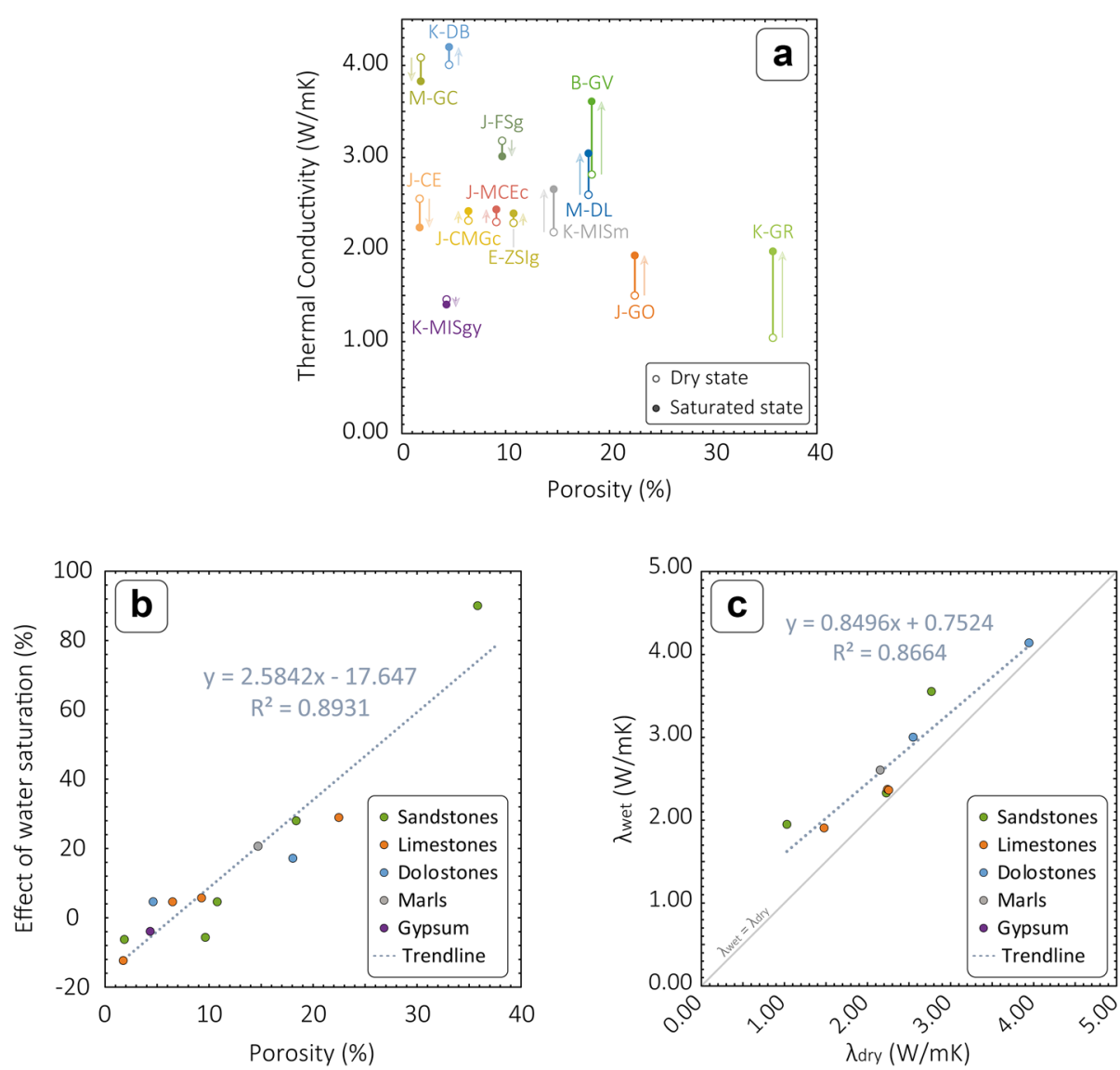

Fig. 7 a Thermal conductivity of the samples in the dry state at ambient temperature (empty circles) and in the saturated state at ambient temperature (filled circles) as a function of porosity. Lines join the dry and saturated conductivity values for the same sample and arrows indicate the direction of variation from dry to saturated. Colors indicate the lithology. $\mathbf{b}$ Effect of water saturation on thermal conductivity as a function of porosity of individual samples. Trendline and corresponding equation and coefficient of determination, $R^{2}$, are given. c Comparison of thermal conductivities measured under dry state $\left(\lambda_{\text {dry }}\right)$ and water-saturated state $\left(\lambda_{\text {wet }}\right)$. Trendline and corresponding equation and coefficient of determination, $R^{2}$, are given. The equation of the trendline is used for wet thermal conductivity estimates for samples measured only in the dry state 
conductivity between the dry, $\lambda_{\mathrm{dry}}$, and saturated, $\lambda_{\text {wet }}$, state by defining an "effect of water saturation", $\left(\lambda_{\text {wet }}-\lambda_{\text {dry }}\right) / \lambda_{\text {dry }} \times 100$. The effect of water saturation is plotted as a function of porosity in Fig. 7b. This figure shows that the influence of water saturation on the thermal conductivity increases as porosity increases and that the data can be well described by a linear trend. Increases in thermal conductivity are small for low-porosity samples (less than 5\%), high for high-porosity samples (up to 90\%) and appear independent of lithology (Fig. 7b). We further note that, regardless of lithology, the thermal conductivity of the saturated samples is linearly related to their dry thermal conductivities (Fig. 7c, samples with thermal conductivity higher in the dry state than in the wet state are not included).

\section{Dry-state samples at high temperature}

Thermal conductivity is plotted as a function of temperature in Fig. 8, which shows that, for all lithologies, thermal conductivity decreases with increasing temperature.

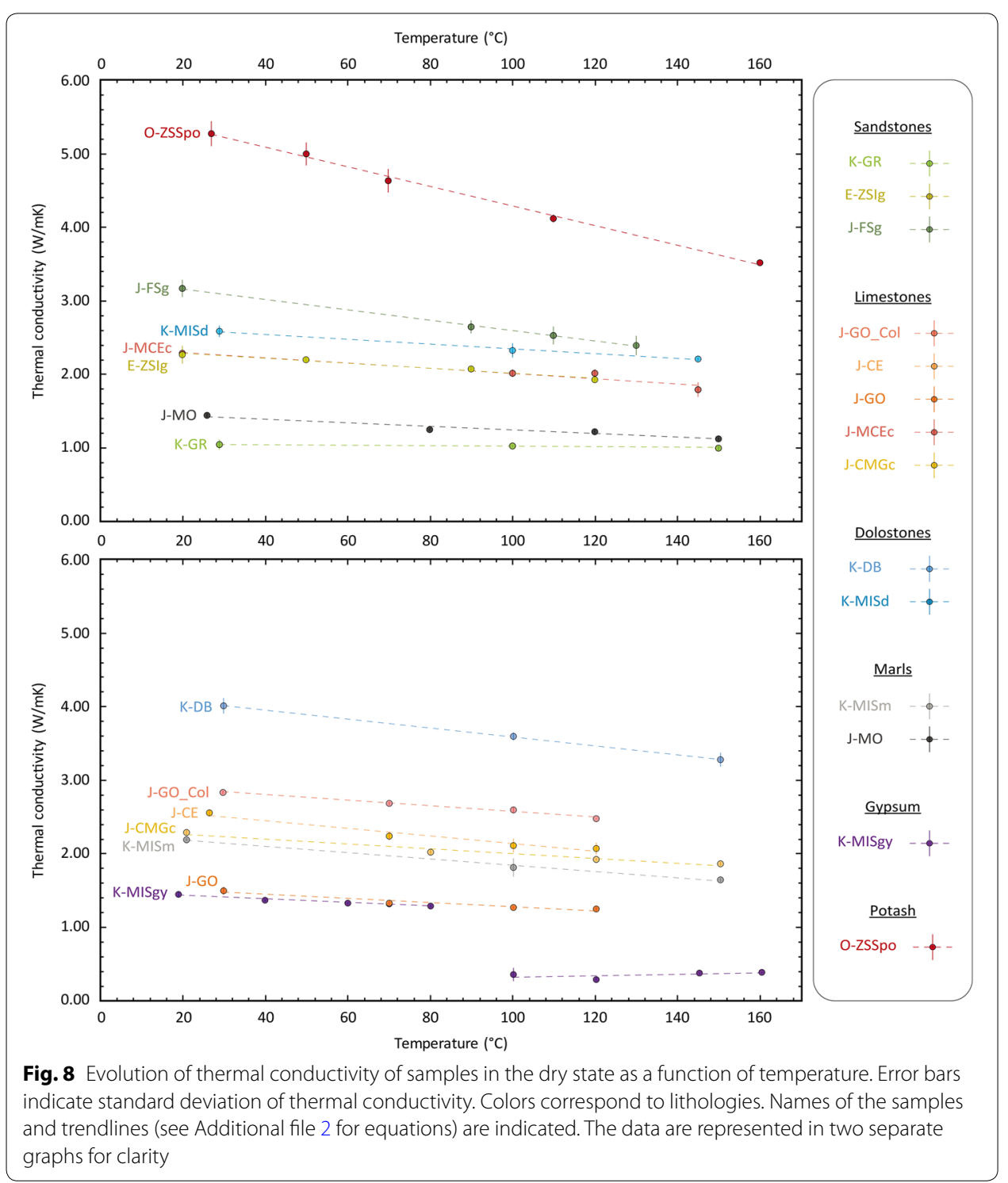




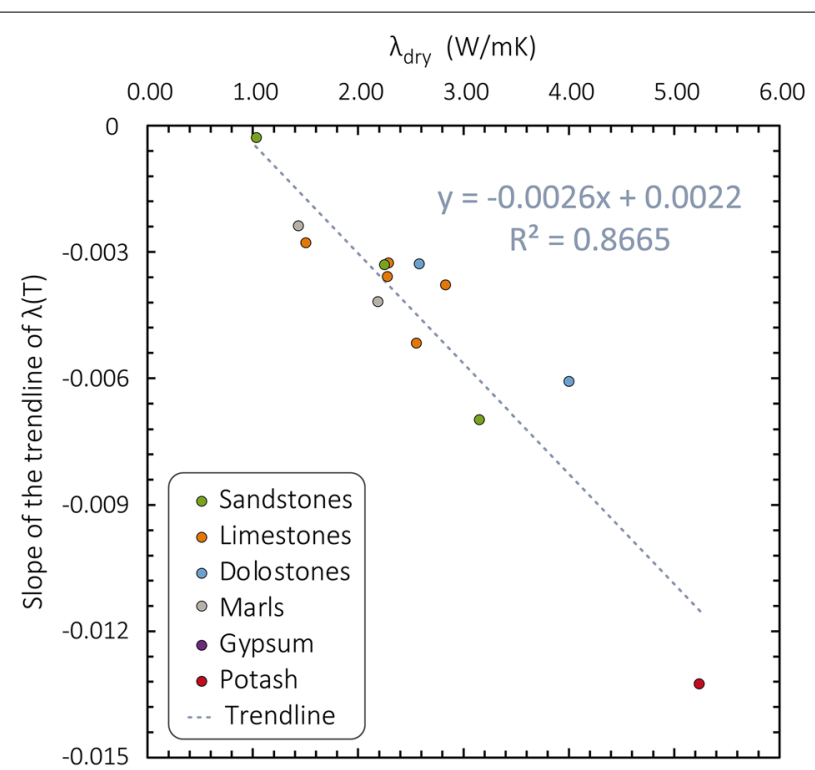

Fig. 9 Slope of the trendlines of dry thermal conductivity as a function of temperature (see Fig. 8, equations in Additional file 2) as a function of thermal conductivity of the corresponding sample in the dry state at ambient temperature $\left(\lambda_{\text {dry }}\right)$. Trendline and corresponding coefficient of determination, $R^{2}$, are represented. Colors correspond to lithologies. Equation of the trendline is used to estimate thermal conductivity at a given temperature from dry conductivity of the sample

Thermal conductivity as a function of temperature is well described by a linear trend (with coefficients of determination, $\mathrm{R}^{2}$, above 0.91; see Additional file 2), apart from gypsum sample K-MISgy above $80{ }^{\circ} \mathrm{C}\left(\mathrm{R}^{2}=0.34\right.$; see Additional file 2$)$. Indeed, the K-MISgy gypsum sample shows a decrease similar to that of the other samples below $80{ }^{\circ} \mathrm{C}$ but reveals a sharp decrease in thermal conductivity above that limit, from $1.30 \mathrm{~W} / \mathrm{mK}$ at $80{ }^{\circ} \mathrm{C}$ to $0.36 \mathrm{~W} / \mathrm{mK}$ at $100{ }^{\circ} \mathrm{C}$. Thermal conductivity of the sample slightly increases above $100^{\circ} \mathrm{C}$.

The thermal conductivities of the samples with the lowest thermal conductivities at ambient temperature appear to be influenced less by an increase in temperature. For example, the high-conductivity O-ZSSpo potash sample is more affected $(12 \%$ conductivity decrease) by a $43{ }^{\circ} \mathrm{C}$ temperature increase than the low-thermal-conductivity K-GR sandstone sample is by a $121{ }^{\circ} \mathrm{C}$ temperature increase ( $4 \%$ conductivity decrease).

To emphasize the influence of the dry thermal conductivity, the slopes of the linear trends of thermal conductivity as a function of temperature (see Additional file 2 for equations) are plotted as a function of thermal conductivity at ambient temperature in Fig. 9. The K-MISgy gypsum sample is not represented in this graph due to its atypical temperature dependence. This figure shows that the influence of temperature on the thermal conductivity of our sample suite depends on the dry thermal conductivity and that the data can be well described by a linear trend. 


\section{Discussion}

The large thermal conductivity and porosity ranges measured in this study suggest that these values are the result of interaction between several parameters. The variability in measured porosities, from near-zero to $44 \%$ depending on lithology, indicates that no characteristic value exists for a given lithology. Therefore, a precise measurement of the porosity of all rocks is required to properly quantify the influence of this property on thermal conductivity of rocks.

\section{Thermal conductivity}

\section{Dry-state samples at ambient temperature}

Thermal conductivity ranges are large for each rock type, highlighting that thermal conductivity does not only depend on lithology and there is no characteristic conductivity for a given lithology.

The measurements allowed us to observe a first-order relation between the thermal conductivities of the samples and their porosities for all lithologies: thermal conductivity decreases with increasing porosity as observed in previous studies (Popov et al. 2003; Nagaraju and Roy 2014; Guo et al. 2017; Mielke et al. 2017).

As shown by Fig. 5 , the range of thermal conductivity values is small for porous rocks $(\phi>25 \%)$, regardless of lithology and, thus, composition, which indicates that porosity is a predominant factor controlling thermal conductivity of porous rocks. On the contrary, for less porous rocks $(\phi<14 \%)$, conductivity values show more variability and depend more on the lithology, which suggests a higher effect of mineralogical composition of the sample.

\section{Saturated-state samples at ambient temperature}

Many studies have shown that measurements on samples in the dry state often underestimate thermal conductivity of porous rocks due to the low conductivity of air in the pores (Nagaraju and Roy 2014). Furthermore, measurements on saturated samples are often more representative of the in situ conditions since the pore volume is generally filled with water or other liquids that have higher thermal conductivities than air $\left(\lambda_{\text {water }}=0.6 \mathrm{~W} / \mathrm{mK}\right.$ ) (Nagaraju and Roy 2014; Vosteen and Schellschmidt 2003). The results show an influence of saturation for all the investigated samples. Thermal conductivity in the saturated state is generally higher than in the dry state (Fig. 7a). For water-saturated samples, the contrast in thermal conductivity between the rock matrix and the fluid in the pores is smaller than for dry rocks, hence the observed trend for the sedimentary rock samples of this study. However, this trend does not apply to the M-GC shelly sandstone (Grès Coquillier, Muschelkalk), the J-FSg calcareous sandstone (Formation de Schalkendorf, Jurassic), the J-CE limestone (Calcaire d'Ettendorf, Jurassic) and to the K-MISgy gypsum (Marnes Irisées supérieures, Keuper). These samples show a low porosity $(\phi<10 \%)$ and thermal conductivity higher in the dry state than in the saturated state as observed in previous studies by Nagaraju and Roy (2014) and Albert et al. (2017) for sedimentary rocks with porosity smaller than 3\%. According to Albert et al. (2017), some rocks react to the fluid used for saturation, resulting in dissolution of some mineral and/or modification of the structure of the rock matrix of the sample and thus of its thermal conductivity. It is plausible that this phenomenon could have impacted our 
samples. The very low porosity of these rocks, and therefore its very low influence of the pore space on conductivity, would have allowed us to observe the decrease in thermal conductivity of the rock matrix due to saturation. For more porous samples, the effect of porosity on conductivity is more significant and could have masked the impact of interaction between water and the rock matrix.

As shown by Fig. 7b, the effect of water saturation strongly depends on the porosity of the sample and very little on the sample's mineralogy. This relationship has already been observed in sedimentary rocks by Popov et al. (2003) and Nagaraju and Roy (2014).

However, thermal conductivity measured on saturated samples could not be correlated with the porosity of the samples. According to Popov et al. (2003), this can be explained by the variability of thermal conductivity of the rock matrix of the studied samples and in particular by the influence of the clay content. In the saturated state, the contrast between thermal conductivity of the matrix and that of the fluid filling the pores is smaller than for dry rocks. It is thus possible that the influence of composition of the rock matrix on thermal conductivity in the saturated state is more important than that of porosity.

Finally, thermal conductivity of the saturated samples is linearly proportional to thermal conductivity of the dry samples (Fig. 7c): thermal conductivity in the saturated state increases with increasing conductivity in the dry state, as observed by Guo et al. (2017) for sandstones. This relationship allows us to estimate conductivity of a sample in the water-saturated state at ambient temperature using the dry-state measurement at room temperature (Eq. 8).

\section{Dry-state samples at high temperature}

Many studies have shown that thermal conductivity of dry rocks tends to decrease with increasing temperature (between -80 and $100{ }^{\circ} \mathrm{C}$ by Guo et al. 2017; in the temperature range from 25 to $500{ }^{\circ} \mathrm{C}$ by Kant et al. 2017 and between 0 and $300{ }^{\circ} \mathrm{C}$ by Vosteen and Schellschmidt 2003). According to Guo et al. (2017), temperature is one of the factors which has the most impact on thermal conductivity of a solid. These studies also showed that the decrease in thermal conductivity with increasing temperature is nonlinear. Therefore, performing measurements at relevant in situ temperatures is essential and the experimental conditions should be as close as possible to in situ conditions. This choice is even more important since, in this study, we cannot perform measurements on water-saturated samples at high temperature nor can we study the effect of pressure (closer to in situ conditions) due to equipmental constraints.

The results of high-temperature measurements show an approximate negative linear correlation between thermal conductivity and increasing temperature (Fig. 8 and Additional file 2). It should, however, be emphasized that the temperature ranges chosen for this study (between 18 and $160{ }^{\circ} \mathrm{C}$ ) are less extensive than the ones considered for the studies previously mentioned. These trends can be used to interpolate/extrapolate thermal conductivity at a given temperature for these dry samples and those for which they are used as proxies.

We find that thermal conductivity of dry rocks decreases with increasing temperature, as shown previously by Kant et al (2017), Guo et al. (2017), Vosteen and Schellschmidt (2003) and Clauser and Huenges (1995). Since, at ambient pressure, the thermal 
conductivity of air only increases from 0.025 to $0.036 \mathrm{~W} / \mathrm{mK}$ as temperature is increased from 20 to $150^{\circ} \mathrm{C}$ (Kadoya et al. 1985), we attribute this decrease to changes in the thermal conductivity of the rock matrix with increasing temperature. We also cannot rule out decreases in thermal conductivity as a result of increases in porosity due to thermal microcracking (Chaki et al. 2008; Griffiths et al. 2018; Kant et al. 2017) and/or chemical reactions such as the dehydroxylation of clays (Earnest 1991a, b; Mollo et al. 2011), especially at temperatures in excess of $100{ }^{\circ} \mathrm{C}$. The sharp decrease in thermal conductivity of the K-MISgy gypsum above $80{ }^{\circ} \mathrm{C}$ can be easily explained by the progressive transformation of gypsum $\left(\mathrm{CaSO}_{4} 2 \mathrm{H}_{2} \mathrm{O}\right)$ to bassanite (hemihydrate $\left.\mathrm{CaSO}_{4}{ }^{1 / 2} \mathrm{H}_{2} \mathrm{O}\right)$ (i.e., partial dehydration of gypsum) (Sadeghiamirshahidi and Vitton 2019). The slight increase in thermal conductivity with increasing temperature above this limit can be caused by transformation of the small amount of gypsum that had been left un-transformed in the sample into bassanite.

Yet we observe that some samples are more affected by temperature increase. Thermal conductivity of the high-conductivity O-ZSSpo potash decreases more than that of the K-GR sandstone despite a greater temperature increase for the latter. We propose that the higher the initial thermal conductivity measured on a dry sample at room temperature, the more it is affected by temperature increase (Figs. 8 and 9) as observed by Vosteen and Schellschmidt (2003). This relationship, which can be satisfactorily characterized by a linear trendline $\left(R^{2}=0.87\right)$, could be used to calculate an estimated thermal conductivity at a given temperature using the dry-state measurements at room temperature (Eq. 5).

\section{Heat flow density estimations}

\section{Methods for heat flow density estimations}

Based on the various thermal conductivity measurement conditions, three types of heat flow density were calculated for each site: (1) dry rocks at ambient temperature ("dry" heat flow density); (2) dry rocks at in situ temperature ("hot" heat flow density), and (3) saturated rocks at ambient temperature ("wet" heat flow density).

For the dry heat flow density estimates, the thermal conductivities measured on the samples in the laboratory were considered without corrections for in situ temperature or water saturation.

For the hot heat flow density estimates, the thermal conductivities of the samples were either taken directly from the data (if the sample was measured at the in situ temperature) or the thermal conductivity at ambient temperature was corrected for the in situ temperature. To perform this correction, we interpolate/extrapolate the existing data using the empirical relationships defined in this study. For samples measured under dry, hot conditions, the decrease in thermal conductivity with temperature can be described by the following linear equation:

$$
\lambda(T)=a T+b,
$$

where $\lambda(T)$ is the thermal conductivity (in $\mathrm{W} / \mathrm{mK}$ ) at temperature $T$ (in ${ }^{\circ} \mathrm{C}$ ), and empirical constants $a$ and $b$ are given by the best-fit linear regression of the data provided in Fig. 8 (equations provided in Additional file 2). The $a$ coefficient of each of the linear trendlines is plotted in Fig. 9 as a function of the dry thermal conductivity at ambient 
temperature, $\lambda_{\mathrm{dry}}$, of the associated sample. The best-fit linear regression of this plot provides the following equation:

$$
a=-0.0026 \times \lambda_{\mathrm{dry}}+0.0022 .
$$

Thus giving:

$$
\lambda(T)=\left(-0.0026 \times \lambda_{\mathrm{dry}}+0.0022\right) \times T+b .
$$

The mean measuring temperature of the dry measurements is applied as a correction coefficient for T to average $b$ as measured $\lambda_{\text {dry }}$. The thermal conductivity $\lambda_{\text {hot }}$ at the in situ temperature $T_{\text {in situ }}$, can therefore be approximated from the dry thermal conductivity at ambient temperature, using the following relation:

$$
\lambda_{\text {hot }}=\left[\left(-0.0026 \times \lambda_{\text {dry }}\right)+0.0022\right] \times\left(T_{\text {in situ }}-25\right)+\lambda_{\text {dry }} .
$$

For the gypsum-bearing formations, two equations (corresponding to equations of the best-fit linear regressions, Fig. 8 and Additional file 2) were considered to estimate hot thermal conductivity of the gypsum:

Below $80{ }^{\circ} \mathrm{C}$ :

$$
\lambda_{\text {hot }}=-0.0024 \times T_{\text {in situ }}+1.4852 .
$$

Above $80{ }^{\circ} \mathrm{C}$ :

$$
\lambda_{\text {hot }}=0.001 \times T_{\text {in situ }}+0.2337 \text {. }
$$

For the wet heat flow density estimates, the thermal conductivities of the samples were either taken directly from the data (if the sample was measured in the saturated state) or the thermal conductivity at ambient temperature was corrected for water saturation using the relationship defined by all our wet data (Fig. 7c). The wet thermal conductivity, $\lambda_{\text {wet }}$ (in $\mathrm{W} / \mathrm{mK}$ ), can be estimated from the dry thermal conductivity at ambient temperature using the following empirical relationship (Fig. 7c):

$$
\lambda_{\text {wet }}=\left(0.8496 \times \lambda_{\text {dry }}\right)+0.7524 .
$$

Samples with a thermal conductivity higher in the dry state than in the water-saturated state are not included since thermal conductivity is expected to increase with water saturation.

For the three types of heat flow density, a mean thermal conductivity was calculated for each sedimentary formation observed in the borehole. The composition of the formations (proportions of sandstone, marls, dolostone, etc.) was estimated based on the GRT-1 masterlog (Duringer and Orciani (2015), internal report). The mean thermal conductivity of the formation, $\lambda_{\text {form }}$, was calculated as the weighted harmonic mean of the thermal conductivities of the samples composing the formation (Beardsmore et al. 2001).

For the formations that were not sampled, the mean thermal conductivity of a formation with similar geological characteristics was used. 
The three types of heat flow density were calculated using the equilibrated thermal profiles measured in the wells (Baujard et al. (2017) for Rittershoffen and Genter et al. (2010) for Soultz-sous-Forêts) and the mean thermal conductivities of the formations $\lambda_{\text {form }}$. The depths of the limits (top $z_{\text {top form }}$ and bottom $z_{\text {bot form }}$ ) of the formations were taken from Duringer et al. (2019) for the Rittershoffen site and from Aichholzer et al. (2016) for the Soultz-sous-Forêts site. The heat flow densities were calculated for each formation between the surface and the top of the Muschelkalk using Fourier's law:

$$
q_{\text {form }}=\lambda_{\text {form }} \times \frac{T_{\text {bot form }}-T_{\text {top form }}}{z_{\text {bot form }}-z_{\text {top form }}},
$$

where $q_{\text {form }}$ is the heat flow density of the formation (in $\mathrm{W} / \mathrm{m}^{2}$ ), $\lambda_{\text {form }}$ is the mean thermal conductivity of the sedimentary formation (in $\mathrm{W} / \mathrm{mK}$ ), and $T_{\text {top form }}$ and $T_{\text {bot form }}$ are the temperatures measured in the well at the top and bottom of the formation, respectively.

For all sites, we define mean heat flow densities for four intervals (1) the whole sedimentary cover in the conduction zone (between the surface and the top of the Muschelkalk, "global" heat flow density), considered as the "equilibrium" heat flow density and for the (2) Tertiary, (3) Jurassic and (4) the Keuper intervals to study the evolution of heat flow density with depth.

For each interval, a mean thermal conductivity $\overline{\lambda_{\text {interval }}}$ (in $\mathrm{W} / \mathrm{mK}$ ) was calculated as the harmonic mean of the thermal conductivities of the formations within the interval weighted by the thickness of the formations. This mean thermal conductivity was used to calculate $\overline{q_{\text {interval }}}$ the mean heat flow density $\left(\right.$ in $\mathrm{W} / \mathrm{m}^{2}$ ) of the considered interval, such as:

$$
\overline{q_{\text {interval }}}=\overline{\lambda_{\text {interval }}} \times \frac{T_{\text {bot interval }}-T_{\text {top interval }}}{z_{\text {bot interval }}-z_{\text {top interval }}},
$$

where $T_{\text {bot interval }}$ and $T_{\text {top interval }}$ are the temperatures (in ${ }^{\circ} \mathrm{C}$ ) at the top and bottom of the interval, respectively, and $z_{\text {bot interval }}$ and $z_{\text {top interval }}$ are the depths (in $\mathrm{m}$ ) of the top and bottom limits of the considered interval, respectively. A detailed description of the equations and error calculation are provided in Additional file 3.

The first meters of the boreholes were filled with air when the equilibrium-temperature profiles were assessed in the geothermal wells. Therefore, the temperature was considered only where measurements were performed in brine, from depths of 50 and 40.3 meters in GPK-1 and GPK-2, respectively. For GRT-1, the first $149.8 \mathrm{~m}$ were not included in the heat flow density calculations.

\section{Estimated heat flow densities}

Conductive heat flow density was calculated for each geothermal well (GPK-1 and GPK-2 in Soultz-sous-Forêts and GRT-1 in Rittershoffen) from the equilibrium-temperature profiles measured in the wells and from the thermal conductivities measured on (1) dry rocks at ambient temperature ("dry"), (2) dry rock at in situ temperature ("hot") and (3) saturated rocks at ambient temperature ("wet"). The results are 


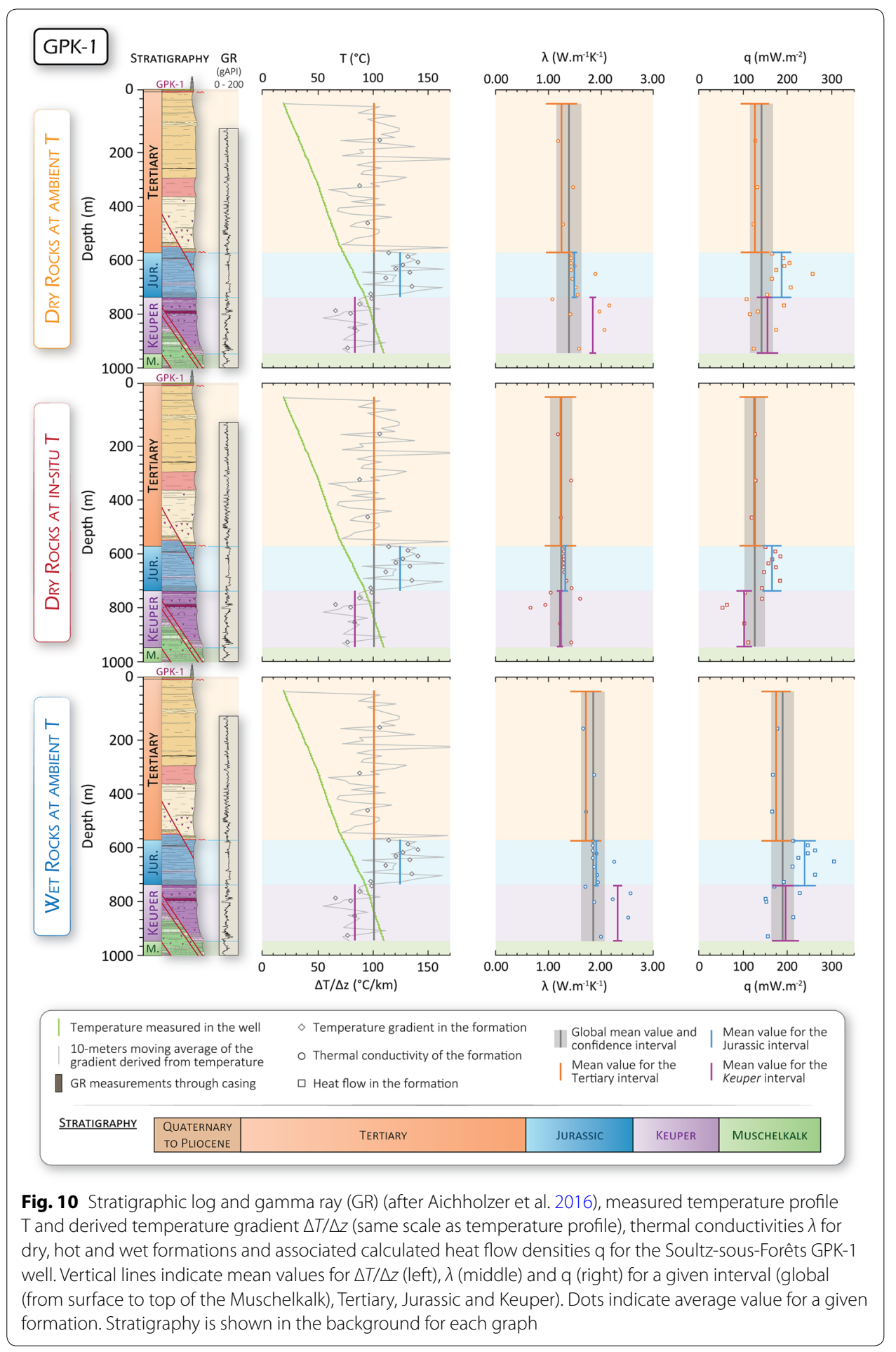

presented in Figs. 10, 11 and 12 for GPK-1, GPK-2 and GRT-1, respectively. All the mean values are compiled in Table 1.

The temperature gradient is higher (3-23\%) than the global gradient (mean temperature gradient of the whole sedimentary column, between the surface and the top 


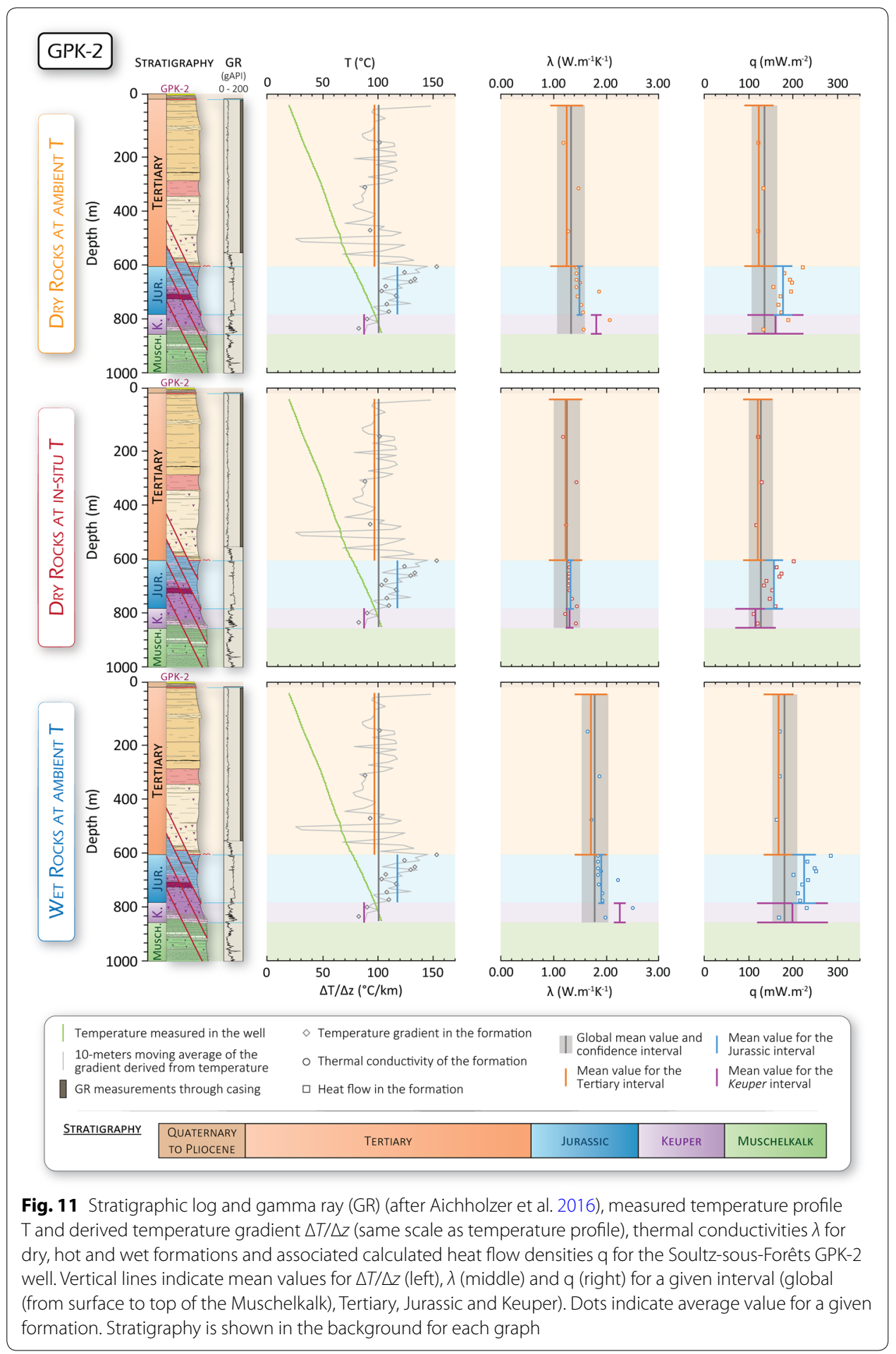

of the Muschelkalk) in the Tertiary in GRT-1 and in the Jurassic in all the wells. Gradients in the other intervals are lower (3-17\%) than the global gradients.

For all the wells and all conditions considered, thermal conductivity in the Tertiary interval is always inferior (by $8 \%$ ) or equal to the global thermal conductivity. The 


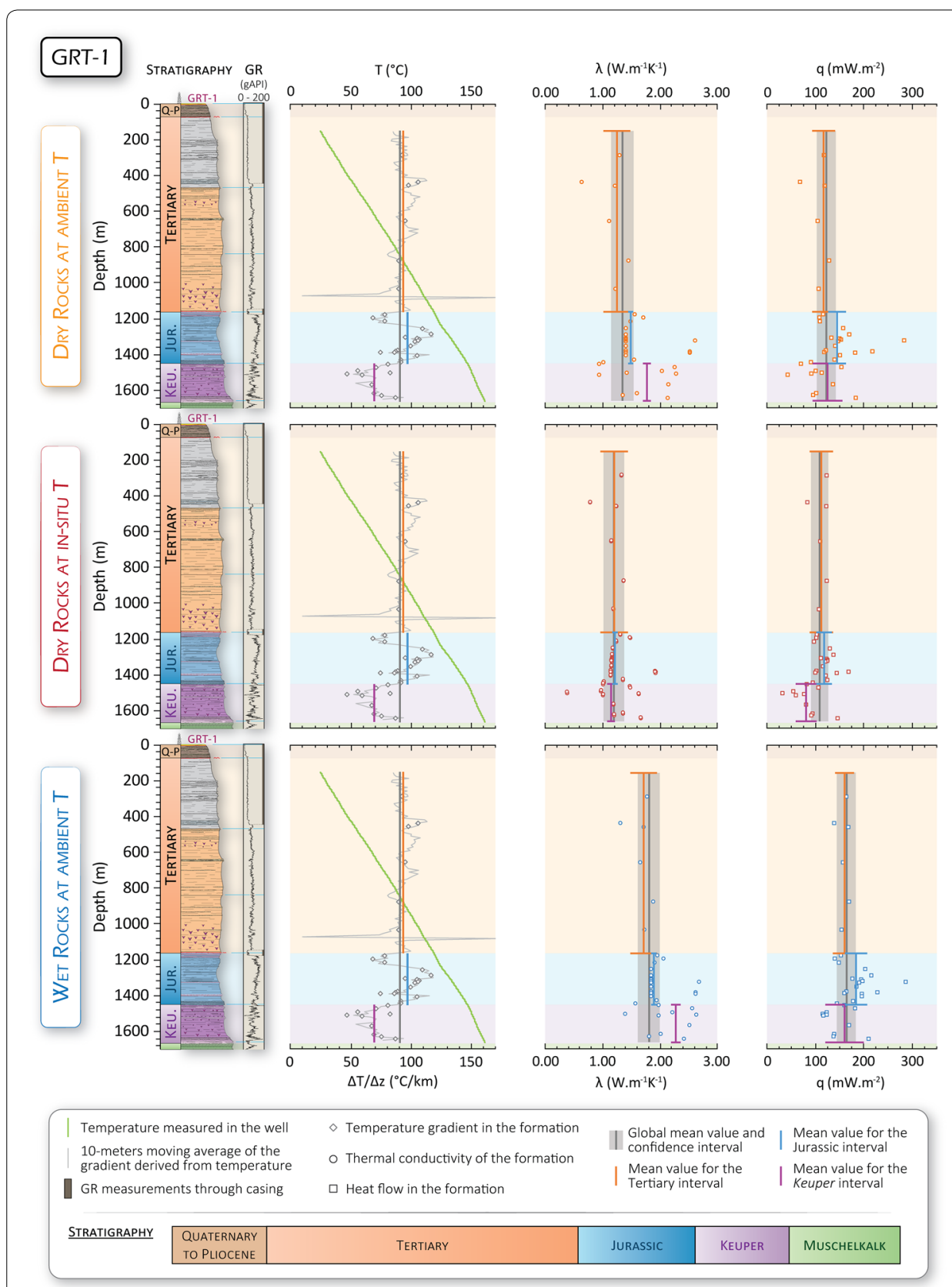

Fig. 12 Stratigraphic log and gamma ray (GR) (after Duringer et al. 2019), measured temperature profile T and derived temperature gradient $\Delta T / \Delta z$ (same scale as temperature profile), thermal conductivities $\lambda$ for dry, hot and wet formations and associated calculated heat flow densities q for the Rittershoffen GRT-1 well. Vertical lines indicate mean values for $\Delta T / \Delta z$ (left), $\lambda$ (middle) and q (right) for a given interval (global (from surface to top of the Muschelkalk), Tertiary, Jurassic and Keuper). Dots indicate average value for a given formation. Stratigraphy is shown in the background for each graph

hot thermal conductivities of the Keuper interval in GRT-1 and GPK-1 are also lower $(2-4 \%)$ than the global thermal conductivity. Values for the other intervals are higher (4-37\%) than the global thermal conductivity. 
Table 1 Mean calculated thermal conductivities $\lambda$ and heat flow densities $q$ for the various intervals in the GRT-1, GPK-1 and GPK-2 geothermal wells

\begin{tabular}{|c|c|c|c|c|c|c|c|c|c|}
\hline \multirow[t]{2}{*}{ Well } & \multirow[t]{2}{*}{ Interval } & \multirow{2}{*}{$\begin{array}{l}\text { Mean } T \\
\left({ }^{\circ} \mathrm{C}\right)\end{array}$} & \multirow{2}{*}{$\begin{array}{l}\Delta T / \Delta z \\
\left({ }^{\circ} \mathrm{C} / 100 \mathrm{~m}\right)\end{array}$} & \multicolumn{2}{|l|}{ Dry } & \multicolumn{2}{|l|}{ Hot } & \multicolumn{2}{|l|}{ Wet } \\
\hline & & & & $\begin{array}{l}\text { Mean } \lambda(W / \\
\mathrm{mK})\end{array}$ & $\begin{array}{l}\text { Mean } q \\
\left(\mathrm{~mW} / \mathrm{m}^{2}\right)\end{array}$ & $\begin{array}{l}\text { Mean } \lambda(W / \\
\mathrm{mK})\end{array}$ & $\begin{array}{l}\text { Mean } q \\
\left(\mathrm{~mW} / \mathrm{m}^{2}\right)\end{array}$ & $\begin{array}{l}\text { Mean } \lambda(W / \\
\mathrm{mK})\end{array}$ & $\begin{array}{l}\text { Mean } \\
q(\mathrm{~mW} / \\
\left.\mathrm{m}^{2}\right)\end{array}$ \\
\hline \multirow[t]{4}{*}{ GRT-1 } & Global & 92.54 & 9.07 & $1.35 \pm 0.20$ & $122 \pm 19$ & $1.20 \pm 0.18$ & $109 \pm 18$ & $1.81 \pm 0.19$ & $164 \pm 20$ \\
\hline & Tertiary & 71.59 & 9.32 & $1.25 \pm 0.24$ & $117 \pm 24$ & $1.20 \pm 0.24$ & $112 \pm 24$ & $1.71 \pm 0.23$ & $159 \pm 24$ \\
\hline & Jurassic & 132.30 & 9.69 & $1.49 \pm 0.04$ & $144 \pm 18$ & $1.22 \pm 0.05$ & $118 \pm 16$ & $1.90 \pm 0.05$ & $184 \pm 22$ \\
\hline & Keuper & 153.25 & 7.03 & $1.77 \pm 0.07$ & $125 \pm 31$ & $1.15 \pm 0.07$ & $81 \pm 22$ & $2.27 \pm 0.08$ & $160 \pm 39$ \\
\hline \multirow[t]{4}{*}{ GPK-1 } & Global & 64.49 & 10.13 & $1.40 \pm 0.24$ & $141 \pm 26$ & $1.25 \pm 0.21$ & $126 \pm 23$ & $1.85 \pm 0.23$ & $188 \pm 26$ \\
\hline & Tertiary & 46.02 & 10.08 & $1.25 \pm 0.30$ & $126 \pm 32$ & $1.23 \pm 0.30$ & $124 \pm 32$ & $1.71 \pm 0.29$ & $172 \pm 32$ \\
\hline & Jurassic & 83.07 & 12.46 & $1.50 \pm 0.05$ & $187 \pm 22$ & $1.32 \pm 0.06$ & $165 \pm 21$ & $1.91 \pm 0.05$ & $238 \pm 25$ \\
\hline & Keuper & 101.54 & 8.37 & $1.85 \pm 0.06$ & $155 \pm 24$ & $1.22 \pm 0.06$ & $102 \pm 17$ & $2.32 \pm 0.09$ & $194 \pm 31$ \\
\hline \multirow[t]{4}{*}{ GPK-2 } & Global & 62.34 & 10.14 & $1.33 \pm 0.26$ & $135 \pm 29$ & $1.26 \pm 0.25$ & $127 \pm 27$ & $1.78 \pm 0.25$ & $181 \pm 28$ \\
\hline & Tertiary & 49.00 & 9.78 & $1.25 \pm 0.31$ & $123 \pm 33$ & $1.23 \pm 0.32$ & $120 \pm 33$ & $1.71 \pm 0.31$ & $167 \pm 33$ \\
\hline & Jurassic & 87.60 & 11.82 & $1.50 \pm 0.05$ & $177 \pm 21$ & $1.32 \pm 0.06$ & $157 \pm 20$ & $1.90 \pm 0.05$ & $225 \pm 25$ \\
\hline & Keuper & 100.95 & 8.81 & $1.82 \pm 0.10$ & $160 \pm 63$ & $1.31 \pm 0.07$ & $115 \pm 45$ & $2.26 \pm 0.12$ & $199 \pm 77$ \\
\hline
\end{tabular}

Mean measured temperatures and temperature gradients are given for the various intervals [global (from surface to top of the Muschelkalk), Tertiary, Jurassic and Keuper]. Data for dry rocks at ambient temperature (dry), dry rocks at in situ temperature (hot) and saturated rocks at ambient temperature (wet)

In the GRT-1 well, the calculated mean global heat flow densities are $122 \mathrm{~mW} / \mathrm{m}^{2}$ $( \pm 16 \%), 109 \mathrm{~mW} / \mathrm{m}^{2}( \pm 16 \%)$ and $164 \mathrm{~mW} / \mathrm{m}^{2}( \pm 12 \%)$ for dry, hot and wet rocks, respectively. In GPK-1, the global heat flow densities are $141 \mathrm{~mW} / \mathrm{m}^{2}( \pm 18 \%), 126$ $\mathrm{mW} / \mathrm{m}^{2}( \pm 18 \%)$ and $188 \mathrm{~mW} / \mathrm{m}^{2}( \pm 14 \%)$ for dry, hot and wet rocks, respectively. In GPK-2, the global heat flow densities are $135 \mathrm{~mW} / \mathrm{m}^{2}( \pm 21 \%), 127 \mathrm{~mW} / \mathrm{m}^{2}( \pm 21 \%)$ and $181 \mathrm{~mW} / \mathrm{m}^{2}( \pm 16 \%)$, for dry, hot and wet rocks, respectively.

Heat flow density calculated for the Jurassic in all the wells and for all conditions is higher $(9-32 \%)$ than the global heat flow density. The same is observed for the hot heat flow density in the Tertiary (3\%) and dry heat flow density in the Keuper at Rittershoffen ( $2 \%$ higher than global heat flow density) and for the dry and wet heat flow densities in the Keuper for the GPK-1 and GPK-2 wells (3-10\% higher). Heat flow densities calculated for all the other intervals are lower $(2-26 \%)$ than global heat flow density.

In summary, at both sites and under all measurement conditions considered, the mean heat flow densities calculated for the Tertiary always fall within the range of variability of the mean global heat flow densities. The same applies for the Keuper in GRT-1 in the dry and wet conditions and for the mean hot and wet heat flow densities in the Jurassic. The mean value calculated for the Jurassic at Rittershoffen for dry rocks is too high to be in the range of variability of the global dry heat flow density. Hot heat flow density in the Keuper is too low to be in the range of variability of the hot mean value.

At Soultz-sous-Forêts, the mean heat flow densities calculated in the Jurassic are systematically out of the interval of the global heat flow densities in GPK-1 and GPK-2. The hot heat flow density calculated in the Keuper in GPK-1 is also too low to be within the 
range of variability of the hot global value. The other values are within the interval of confidence of the global heat flows.

\section{Influence of the thermal-conductivity-measurement conditions}

The dry heat flow densities calculated using the new thermal conductivities values measured in this study on samples from the URG are similar to the previously published heat flow densities for the Soultz-sous-Forêts site and close to Rittershoffen. The heat flow at Soultz-sous-Forêts was estimated in previous studies to be between 140 and $150 \mathrm{~mW} / \mathrm{m}^{2}$ (Flores Marquez 1992; Le Carlier et al. 1994; Schellschmidt and Clauser 1996; Pribnow and Clauser 2000; Baillieux et al. 2013) and we estimate here heat flow densities of $141 \pm 18 \mathrm{~mW} / \mathrm{m}^{2}$ for GPK-1 (Fig. 10 and Table 1) and $135 \pm 21$ $\mathrm{mW} / \mathrm{m}^{2}$ for GPK-2 (Fig. 11 and Table 1 ). The heat flow density estimated near the Rittershoffen site, $121 \mathrm{~mW} / \mathrm{m}^{2}$, compares well with our estimated value of $122 \pm 16$ $\mathrm{mW} / \mathrm{m}^{2}$ for GRT-1 (Fig. 12 and Table 1).

Our results also show that heat flow density depends strongly on thermal conductivity measurement conditions. Heat flow densities calculated using the thermal conductivities of water-saturated rocks at ambient temperature can be up to $43 \%$ higher than heat flow densities calculated for dry rocks (dry rocks at ambient temperature) (Table 1), and heat flow densities calculated using values measured on hot rocks (dry rocks at in situ temperature) can be up to $11 \%$ lower than "dry" heat flow densities (Table 1). Since the "dry" rock scenario is likely the least realistic, these results probably do not represent the true heat flow density values. Further, dry heat flow densities were already discussed for Soultz-sous-Forêts in previous studies, henceforth we only discuss the hot and wet heat flow density models determined by our study.

It is still unclear whether the in situ rocks are saturated or not; verifying the rock saturation at depth in the geothermal wells is particularly complicated. We therefore cannot conclude on the validity of the wet heat flow densities but, as stated, the effect of saturation of the rocks on the calculated heat flow density should not be ignored. The effect of temperature increase down the borehole, however, is undeniable. Temperature increases with depth, and as shown before, thermal conductivity of rocks decreases with increasing temperature. Consequently, we cannot assert that considering hot rocks is more representative than considering wet rocks since it is very plausible that some formations are both hot and saturated while some others are still effectively dry at the in situ temperature conditions. Although the effect of pressure could not be accounted for, we conclude that the hot and wet heat flow densities calculated for the URG using the thermal conductivity data presented herein are more representative of the in situ conditions than the dry heat flow densities previously calculated.

\section{Evolution of the heat flow density with depth}

In a sedimentary basin in which heat transfer is mostly driven by conduction, heat flow density should remain approximately constant with depth (Andrews-Speed et al. 1984; Schütz et al. 2014). Therefore, examining the vertical heat flow density variations with depth at Soultz-sous-Forêts and Rittershoffen should enable us to investigate conductive equilibrium down the geothermal wells. Heat flow density is considered constant if the intervals of confidence of the heat flow density values in the various intervals (Tertiary, 
Jurassic and Keuper) overlap those of the global heat flow densities (over the whole conduction zone). Variations for the dry heat flow densities will not be discussed here, because, as stated earlier, dry conditions were already investigated by previous studies (Baillieux et al. 2013; Flores Marquez 1992; Pribnow and Clauser 2000; Le Carlier et al. 1994; Schellschmidt and Clauser 1996; Pribnow and Schellschmidt 2000).

In the GRT-1 well, the error bars of the hot or wet heat flow densities over the Tertiary, Jurassic and Keuper intervals all overlap the interval of confidence of the calculated global hot or wet heat flow densities (Table 1 and Fig. 12). Thus, we consider the conductive heat flow density in GRT-1 to be constant for the whole sedimentary cover between the surface and the top of the Muschelkalk; equilibrium thermal conduction of heat controls the evolution of temperature with depth over this interval. At Soultz-sousForêts, with the exception of the wet value for the Jurassic in GPK-2, the error bars of the hot or wet heat flow densities over the Tertiary, the Jurassic and the Keuper intervals all overlap the confidence interval of the global hot or wet heat flow densities (Table 1 and Figs. 10, 11). However, the calculated absolute values of the Jurassic interval in the hot and wet conditions are systematically higher $(2-11 \%)$ than the upper boundary of the global heat flow densities. This anomaly is only observed for the Soultz-sous-Forêts site, in both GPK-1 and GPK-2. Even though errors on the calculated heat flow densities values are large (about $12 \%$ in the Jurassic), the difference between the heat flow densities in the Jurassic and the global heat flow densities are probably significant.

It is necessary here to understand if this recurrent heat flow density anomaly in the Jurassic intersected by the Soultz-sous-Forêts wells is real or the result of a systematic error. The method used in this study is the victim of many sources of errors. First, it is possible that when temperature logs were performed in the wells, the systems were not at thermal equilibrium with the surrounding geological formations (Bullard 1947). The temperature log from GPK-1 used to calculate the heat flow density was measured in June 1997, more than 7 months after hydraulic circulation tests in the wells. In GPK-2, temperature was assessed in July 1999, 3 months after the end of the deepening drilling operations in the granitic basement, the sedimentary cover was already fully cased at that time. These periods without perturbations in the wells should have allowed temperature in the boreholes to equilibrate with the host rocks. Temperature logs in Soultzsous-Forêts are thus considered to be as close as possible to equilibrium (Genter et al. 2010).

Second, the local anomaly in the Jurassic could be induced by the rock sampling method. The temperature logs in Soultz-sous-Forêts indeed reveal a higher gradient in the Jurassic than in the Tertiary or in the Keuper intervals (Table 1 and Figs. 10, 11) (Pribnow and Schellschmidt 2000). Maintaining a constant heat flow density over the three intervals would require lower thermal conductivity values than those measured in the laboratory on the Jurassic samples. There are several possible sources of error due to sampling method. (1) Some formations cannot be cored in a way that allows thermal conductivity measurements, especially in the Jurassic, due to friability of the material. We therefore chose to sample analogue rocks from accessible outcrops, which can feature (thermal) properties different from that of the in situ rocks (Bauer et al. 2017). (2) Not all samples could be measured saturated or at in situ temperature; instead, the hot and wet thermal conductivities are interpolated/extrapolated using the here-defined 
empirical relationship (Figs. 7c, 9 respectively). These empirical relationships may introduce significant errors when estimating hot or wet thermal conductivities and more measurements are required to further refine these equations. Further, the effect of pressure could not be studied on our samples. Based on previous studies (Walsh and Decker 1966; Abdulagatova et al. 2009; Schön and Dasgupta 2015), we would expect pressure to reduce porosity and close microcracks and thus increase thermal conductivity, but the extent of that effect coupled to that of temperature and saturation remain to be quantified for the rocks of the URG. (3) For formations that could not be sampled, the sampled formations were used as proxies. For example, the J-MO sample was sourced from a quarry and was used as an analogue for almost all the marls from the Jurassic; this choice to use an analogue rock may induce errors in thermal conductivity estimates. Yet, we note that the thermal conductivity of the marls at the base of the Jurassic (J-CMGm, Calcaires et Marnes à Gryphées) is not very different from that of the J-MO marls (Additional file 1). We thus consider that the use of these analogues materials as a proxy for all the marls of the Jurassic can be justified.

Third, the composition of the formations (proportions of lithology) was estimated from the GRT-1 masterlog (Duringer and Orciani (2015), internal report). The masterlog itself can bear errors if part of the material in the rock cuttings was lost during cleaning (for example, a greater proportion of marls in the in situ formation than observed in the washed cuttings). Also, the masterlog from the Rittershoffen well might not be completely applicable to the Soultz-sous-Forêts geology due to lateral variation of facies in the formations (Fuchs 2018). However, it is very unlikely that facies of the Triassic and Jurassic formations drastically change over $6 \mathrm{~km}$ of horizontal distance (between Rittershoffen and Soultz-sous-Forêts) as shown by Aichholzer et al. (2016).

While direct downhole measurements of thermal conductivity under in situ conditions are the most applicable and would allow us to verify the reliability of the values measured on outcrop samples, such measurements are rare and more expensive than laboratory measurements (Garibaldi 2010; Harcouët 2005).

Further, paleoclimatic and/or topographic corrections are usually required for heat flow density estimates (Beck 1977; Blackwell et al. 1980; Guillou-Frottier et al. 1998; Jaeger and Sass 1963; Lucazeau and Vasseur 1989; Luijendijk et al. 2011; Majorowicz and Wybraniec 2011; Mareschal et al. 2000; Vasseur 1980) and uncorrected data can yield errors in estimated heat flow densities.

Nevertheless, the gradient in the Jurassic interval of the Soultz-sous-Forêts wells is noticeably higher than in the Rittershoffen well, which leads us to believe that this anomaly cannot only be induced by variations in rock thermal conductivities between the two sites. If the methods are not a source of error, then the heat flow density anomaly observed in the Jurassic interval at Soultz-sous-Forêts could be explained by at least four processes: radiogenic heat production, non-equilibrium conduction of heat, heat flow density refraction or transfer of heat by nonconductive processes.

Radiogenic heat production can contribute significantly to surface heat flow density in sedimentary basins (Frone et al. 2015; Guillou-Frottier et al. 2010; Schütz et al. 2012; Waples 2002). In sediments, radiogenic heat production can be high in some shales especially in those rich in organic matter, like in the black shales of the Toarcian (Jurassic) encountered in the URG (Böcker et al. 2017; Böcker and Littke 2016; Waples 2002). 
Radiogenic heat production can be estimated from gamma-ray (GR) logs performed down boreholes (Bücker and Rybach 1996; Waples 2002). Gamma-ray logging is the continuous quantitative measurement of the natural radioactivity of the formations crossed by a borehole (Serra and Serra 2000). These logs can be performed during or after drilling operations in a tubed or open hole, however the signal (unit: gAPI) measured through casing is attenuated compared to a signal measured in an uncased borehole. GR logs in the GPK-1, GPK-2 and GRT-1 wells are presented in Figs. 10, 11 and 12, respectively (Aichholzer et al. 2016; Duringer et al. 2019). In GPK-1, the GR value in the Tertiary is about 85 gAPI, 100 gAPI in the Jurassic and 81 gAPI in the Keuper. GR was measured through casing in the GPK-2 well in the Tertiary until about $575 \mathrm{~m}$ and is therefore attenuated by the casing and will not be taken into account for comparison. The GR value for the Jurassic in GPK-2 is about 97 gAPI and about 72 gAPI in the Keuper. In GRT-1, the mean GR value in the uncased Tertiary rocks is 80 gAPI and radioactivity is higher in the Jurassic (around 118 gAPI) and in the Keuper (92 gAPI, on average). The natural radioactivity in all three wells is highest in the Jurassic, but not high enough to explain the heat flow density anomaly observed at Soultz-sous-Forêts. Further, if radiogenic heat production was the only source of the locally higher heat flow density, the same anomaly would be observed in Rittershoffen. Thus, while natural radioactivity in the Jurassic formations may contribute to enhancing the thermal gradient over this interval of the borehole, it cannot account for the entire thermal anomaly.

According to Andrews-Speed et al. (1984), conductive thermal equilibrium may not be maintained in a sedimentary basin due to rapid sedimentation and subsidence or to uplift and erosion episodes. High sedimentation rates $(\gg 1 \mathrm{~mm} /$ year) can prevent thermal equilibrium between the deposited sediments and the bedrock (England et al. 1980). Rapid sedimentation can thus lead to a transient temperature gradient and heat flow density in the sedimentary sequence until the cold upper sediments warm up and equilibrate with the hot bedrock (Andrews-Speed et al. 1984). In the URG, sedimentation rates during the Tertiary are less than $1 \mathrm{~mm} /$ year and so the Tertiary and Jurassic sequences should be at thermal equilibrium. Despite this, an episode of uplift and erosion can enhance the conductive heat flow density in the near-surface layers by bringing up deep hot material (Andrews-Speed et al. 1984; England et al. 1980). However, in the URG, the most recent episode of uplift is not recent enough to have a continued influence on conductive heat flow density (Sissingh 1998). Moreover, if uplift and erosion were responsible for the heat flow density anomaly, the heat flow density in the Tertiary would also be affected, which is not the case.

Heat refraction can occur in the case of a thermal conductivity contrast between geological structures (Andrews-Speed et al. 1984; England et al. 1980; Fulton and Saffer 2009; Guillou-Frottier et al. 1996, 2010; Lee and Henyey 1974). In faulted areas, as in the URG, where rock types of different thermal conductivities are brought side by side, refraction of heat can occur and temperature and heat flow density can locally increase towards the most conductive material (Andrews-Speed et al. 1984; Lee and Henyey 1974; Wang et al. 1985). The ratio between thermal conductivities of theoretical mediums 1 and 2 can be expected to be equal to the corresponding heat flow density ratio $\left(\lambda_{1} / \lambda_{2}=q_{1} / q_{2}\right)$ (Lee and Henyey 1974). The Soultz-sous-Forêts wells are located near two major faults (the Kutzenhausen and Soultz-sous-Forêts 


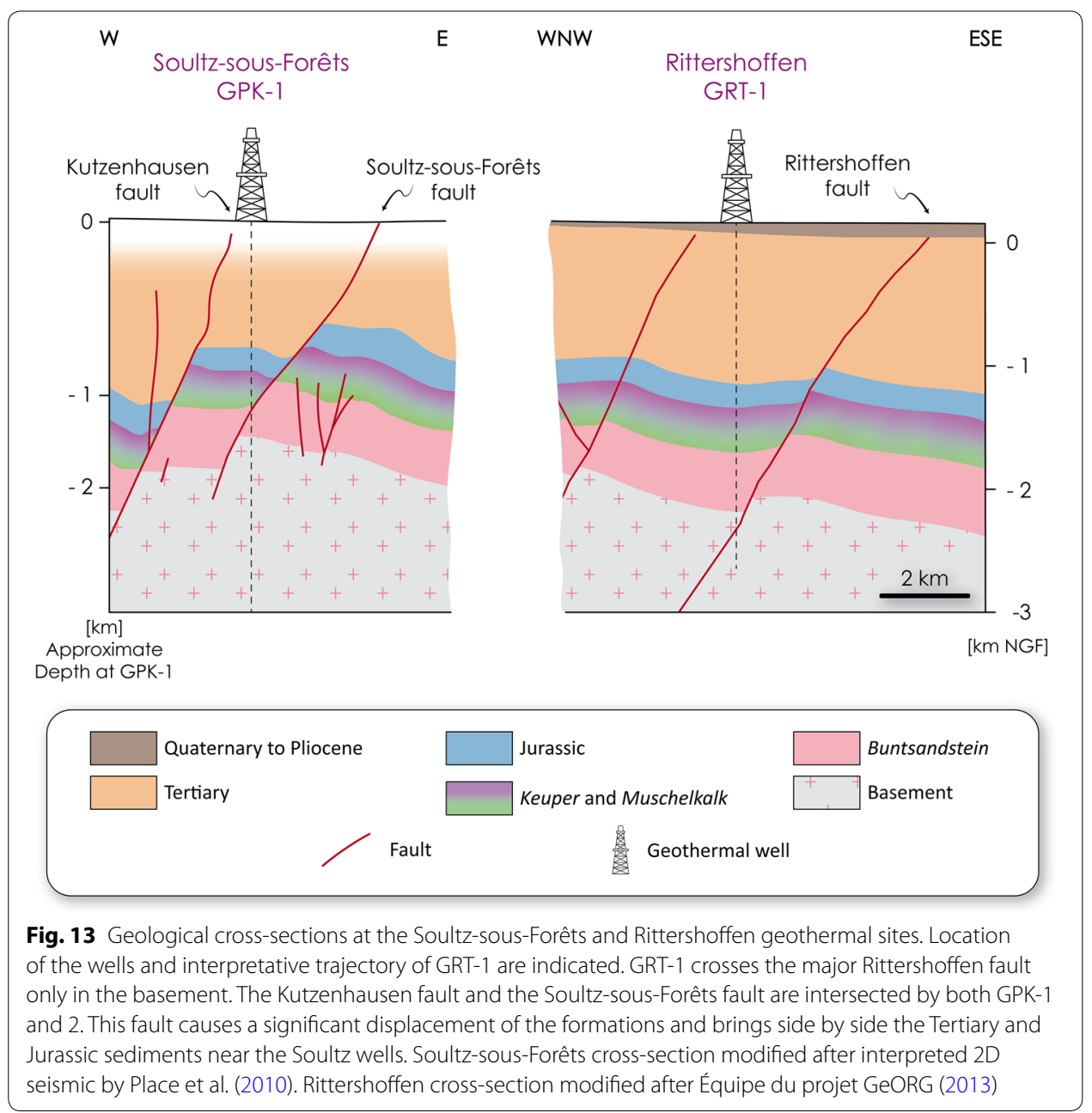

faults, Fig. 13) and cross several faults in the sedimentary cover (Figs. 10 and 11). The Kutzenhausen major fault, imaged using seismic methods and located near the GPK-1 well, has $330 \mathrm{~m}$ of cumulated offset (Aichholzer et al. 2016) and juxtaposes the Jurassic and the Tertiary sediments (Baujard et al. 2017; Place et al. 2010; Vidal et al. 2015). The Jurassic sediments have a higher thermal conductivity than the Tertiary sediments, thus a higher heat flow density can be expected in the Jurassic on the eastern side of the fault. The displacement along the major faults near the Rittershoffen well are not as large as at Soultz-sous-Forêts (Baujard et al. 2017) and GRT-1 only crosses faults in the basement (Duringer et al. 2019), which could imply no or very little heat refraction near the GRT-1 well. A 2D or 3D study of the vertical heat flow density near the Soultz-sous-Forêts and Rittershoffen areas could verify if heat refraction occurs on either side of these major faults. However, the contrast in thermal conductivities between the Tertiary and the Jurassic might not be large enough to fully explain the Jurassic anomaly.

Finally, nonconductive heat transfer might be responsible for the Jurassic temperature anomaly. The GPK wells cross many faults in the sedimentary cover of which some are open fractures, particularly in the Jurassic (Aichholzer et al. 2016). Indeed, 
the GPK-1 well crosses a fracture zone at $639 \mathrm{~m}$ below surface with fractures with apertures on the order of millimeters (oil was detected within these fractures). The GPK-2 well crosses a fracture zone accompanied by a natural gas anomaly at $686 \mathrm{~m}$ and the Soultz-sous-Forêts major fault, also associated with a gas anomaly, at $708 \mathrm{~m}$. If fluid migration (such as water or hydrocarbons) through these fractures occurred, or still occurs, and if the rates of migration exceed a few millimeters per year, the circulation could have induced a local thermal perturbation where the fractures cross the sedimentary formations, generating discontinuities in the heat flow density profiles (Andrews-Speed et al. 1984; Guillou-Frottier et al. 2010). If these fractures reach the basement (which is the case for the Kutzenhausen major fault), the thermal effect of fluid circulation in the faults could be non-negligible (Waples 2002). Further, Le Carlier et al. (1994) have identified the major Soultz-sous-Forêts and the Kutzenhausen faults and the Jurassic formations at Soultz-sous-Forêts as possible fluid pathways. Even if, at present, circulation is not ongoing but stopped recently, the system could be in a transient relaxation phase and may not yet have reached thermal equilibrium and the effect could still be observed in the vertical heat flow density profiles.

We consider nonconductive heat transfer as the process most likely to cause the heat flow density anomaly in the Soultz-sous-Forêts wells. Indeed, faults in the sedimentary cover are only crossed in the GPK wells where the heat flow density anomaly is observed. Faults in the Rittershoffen well, where the vertical heat flow density can be considered stable, were only encountered in the basement.

In summary, a systematic error in estimating thermal conductivities of the formations still needs to be discounted and more measurements are required to refine the URG thermal properties database. The method used to calculate the heat flow densities does not include topographic or paleotemperature corrections, which could also result in error in heat flow density estimates. Yet the heat flow density anomaly observed in the Jurassic at the Soultz-sous-Forêts wells could be the result of a coupled influence of a higher radiogenic heat production in the Jurassic, heat refraction due to the significant displacement caused by the major faults near the Soultz-sous-Forêts geothermal site, and local thermal disturbance caused by (paleo)circulation of hot fluids in the fracture zones crossed by the GPK wells.

\section{Conclusions}

Thermal conductivity and accurate heat flow densities estimates are essential thermal parameters in geothermal studies. This study shows an important influence of the experimental conditions when measuring the thermal properties of rocks. For dry rocks at ambient temperature, conductivity strongly depends on porosity and decreases with increasing porosity. An influence of the mineralogical composition of the rock matrix is also noticeable but is less pronounced. Most samples have higher conductivities in the water-saturated state than in the dry state. Moreover, the effect of water saturation increases with increasing porosity and conductivity in the saturated state is proportional to conductivity in the dry state. Furthermore, results show that thermal conductivity of dry rocks decreases with increasing temperature. The decrease is higher for samples with high conductivity in the dry state at ambient temperature. If the effect of water saturation and temperature are not considered, heat flow density estimates can lead to 
unreliable values. Thus, a good characterization of thermal conductivities of sedimentary formations from the URG crossed by the deep geothermal boreholes combined with the temperature measurements in the wells can provide better estimates of the heat flow density.

The heat flow densities previously reported for the Soultz-sous-Forêts geothermal site relied on a limited dataset, often far from in situ conditions and, until present, no heat flow density has been estimated for the Rittershoffen geothermal borehole. Heat flow density was calculated for both sites using the thermal properties of dry rocks at ambient temperature (dry), dry rocks at in situ temperature (hot) and saturated rocks at ambient temperature (wet). The estimated values illustrate the influence of experimental conditions. Dry heat flow density values calculated using the new thermal conductivity data are consistent with previously published heat flow density values in the Upper Rhine Graben. But dry conditions are considered the least representative of the in situ conditions. Our new thermal properties database now allows us to estimate heat flow density using measurements performed on hot or wet rocks, closer to in situ conditions. The updated heat flow densities calculated for the Soultz-sous-Forêts site are $127 \pm 25 \mathrm{~mW} / \mathrm{m}^{2}$ when considering hot rocks and $184 \pm 15 \mathrm{~mW} / \mathrm{m}^{2}$ when using data for wet rocks. Heat flow density in the GRT-1 well is estimated at $109 \pm 18 \mathrm{~mW} / \mathrm{m}^{2}$ for hot rocks and $164 \pm 20 \mathrm{~mW} / \mathrm{m}^{2}$ for wet rocks. However, although we are sure that temperature increases with depth, the level of saturation of the deep formations is very difficult to assess. We therefore cannot recommend the use of hot conductivity values more than wet values when calculating heat flow densities using the available laboratory data. To improve these estimates, the effect of pressure should also be investigated, and the combined effect of saturation, temperature and pressure needs to be quantified to provide heat flow density estimates as close as possible to the real values.

Variations of vertical heat flow density were studied in the Soultz-sous-Forêts and Rittershoffen wells. Heat flow density in the GRT-1 (Rittershoffen) well is considered stable, but unstable down the GPK-1 and GPK-2 wells (Soultz-sous-Forêts), which both show a positive heat flow density anomaly in the Jurassic. We consider that this anomaly is either the result of systematic error in the methods applied or a combined effect of a higher radiogenic heat production in the Jurassic sediments and thermal disturbance caused by the presence of the major faults close to the Soultz-sous-Forêts geothermal site.

The empirical equations built on the new dataset can provide a good approximation of the wet and hot thermal conductivity of a rock sampled in the URG when its dry thermal conductivity is known. In addition, the new thermal conductivities provided in this study constitute a valuable database that informs our understanding of the existing geothermal sites, the modeling of the thermal field and temperature estimation before drilling operations at prospective sites. Such indications inform the prioritization of future geothermal projects at the basin scale.

Unfortunately, although we consider our heat flow density estimates as the most reliable values currently available for the URG, it is still challenging to comment on the reliability of these estimates using the data (laboratory and field) available to us at this present time. Since heat flow density estimates are important for geothermal site 
prospection in the URG, we consider it important that future studies build on the new insight provided herein.

\section{Supplementary information \\ Supplementary information accompanies this paper at https://doi.org/10.1186/s40517-019-0154-3.}

Additional file 1: Appendix A. Equations of the trendlines of thermal conductivity as a function of temperature shown in Fig. 8. Coefficient of determination $\mathrm{R}^{2}$ are also given. The samples are ordered by lithology.

Additional file 2: Appendix B. Detailed description of the equations presented in the paper and associated error calculation.

Additional file 3: Supplementary materials. Thermal properties database for samples of the Upper Rhine Graben in the dry state at ambient temperature (black), water-saturated state at ambient temperature (blue), dry state at high temperature (red). Samples are in stratigraphical order. Data include lithology, measured porosity, measuring temperature, thermal conductivity and associated standard deviation, thermal diffusivity and associated standard deviation, calculated volumetric heat capacity and associated standard deviation, effect of water saturation and slope of the trendline of thermal conductivity as a function of temperature (Fig. 8).

\section{Abbreviations}

B: Buntsandstein; Dry: dry rocks at ambient temperature; e: thickness; E: Eocene; EGS: Enhanced Geothermal System; gAPI: gamma-ray, American Petroleum Industry (unit); GR: gamma-ray; Hot: dry rock at in situ temperature; J: Jurassic; $\lambda$ : thermal conductivity; $K$ : Keuper; $\lambda_{\text {air }}$ : thermal conductivity of air; $\lambda_{\text {dry }}$ : thermal conductivity of the sample in the dry state at ambient temperature; $\lambda_{\text {form }}$ : thermal conductivity of the sedimentary formation; $\lambda_{\text {hot }}$ : thermal conductivity of the sample in the dry state at the in situ temperature; $\lambda_{\text {samp: }}$ average thermal conductivity of the sample; $\lambda_{\text {water }}$ : thermal conductivity of water; $\lambda_{\text {wet }}$ : thermal conductivity of the sample in the saturated state at ambient temperature; $M$ : Muschelkalk; $m_{d}$ : dry mass of the sample; $m_{i}$ immersed mass of the sample; $m_{w}$ : wet mass of the sample; O: Oligocene; $\phi$ : porosity of the sample; $q$ : conductive heat flow density; $R^{2}$ : determination coefficient of the linear regression; $T$ : temperature; $T_{\text {bot form: }}$ temperature at the bottom of the sedimentary formation; $T_{\text {in situ: }}$ in situ temperature; TPS: Transient Plane Source; $T_{\text {top }}$ form: temperature at the top of the sedimentary formation; URG: Upper Rhine Graben; Wet: saturated rocks at ambient temperature; $x_{\text {samp: }}$ : proportion of the sample in the formation; $z$ : depth; $z_{\text {bot form: }}$ depth of the bottom of the sedimentary formation; $z_{\text {top form: }}$ : depth of the top of the sedimentary formation.

\section{Acknowledgements}

The authors would like to thank John Moine and Bertrand Renaudié for sample preparation. We acknowledge in particular the contribution of Frederick Delay, Laurent Guillou-Frottier and Thierry Reuschlé for their help in the interpretation of the experimental data. The authors are grateful to the Electricité de Strasbourg, ECOGI (Rittershoffen), the GEIE EMC (Soultz-sous-Forêts), and ES-Géothermie for providing access to geological and geophysical log data and core or cutting samples. We also acknowledge the Bureau de Recherches Géologiques et Minières (BRGM) for providing the Pulversheim DP202 borehole cores. Also, the authors would like to thank the anonymous reviewers for their contributions and the improvement of the earlier version of this article.

\section{Authors' contributions}

$\mathrm{PH}$ and PhD collected all the samples. PH performed the thermal property and porosity measurements, data analysis and heat flow density modeling and analysis; and wrote the manuscript, with contributions from all authors. ARLK assisted with the measurements and data analysis and contributed to the interpretation of the data and preparation of the manuscript. CA contributed to fieldwork and preparation of the manuscript. PhD and CA provided geological expertise and contributed to interpretation of the data and figures preparation. PhD led all the field excursions and contributed to paper writing. MJH and PB contributed to paper writing and interpretation of the data. AG, AR, RH and VM provided unpublished data and contributed to interpretation of the data. All authors read and approved the final manuscript.

\section{Funding}

This study was funded by LABEX Grant ANR-11-LABX-0050_G-EAU-THERMIE-PROFONDE (this research, therefore, benefited from state funding managed by the Agence National de la Recherche (ANR) as part of the "Investissements d'avenir" program) and ANR Grant CANTARE (ANR-15-CE06-0014-01). Funding for open access was generously offered by the Helmholtz Centre for Environmental Research-UFZ, Helmholtz Centre Potsdam_GFZ German Research Centre for Geosciences, the Karlsruhe Institute of Technology (KIT), and LABEX Grant ANR-11-LABX-0050_G-EAU-THERMIE-PROFONDE. A part of this work was conducted in the framework of the EGS Alsace project, which was co-funded by ADEME.

\section{Availability of data and materials}

The datasets generated and analyzed during this study are included in this published article in Table 1, Additional file 1 and Additional file 2.

The following datasets are not in the public domain: Masterlog of the GRT-1 well, Soultz-sous-Forêts and Rittershoffen temperature logs (contact: geothermie@es.fr)

\section{Competing interests}

The authors declare that they have no competing interests. 


\begin{abstract}
Author details
1 Institut de Physique du Globe de Strasbourg (IPGS), UMR 7516, CNRS-Université de Strasbourg EOST, 1 Rue Blessig, 67084 Strasbourg Cedex, France. ${ }^{2}$ Géophysique Expérimentale, Institut de Physique du Globe de Strasbourg (IPGS), UMR 7516, CNRS-Université de Strasbourg EOST, 5 Rue René Descartes, 67084 Strasbourg Cedex, France. ${ }^{3}$ ES-Géothermie, Le Belem-5 Rue de Lisbonne, 67300 Schiltigheim, France.
\end{abstract}

Received: 8 November 2019 Accepted: 29 November 2019

Published online: 28 December 2019

\title{
References
}

Abdulagatov IM, Emirov SN, Abdulagatova ZZ, Askerov SY. Effect of pressure and temperature on the thermal conductivity of rocks. J Chem Eng Data. 2006;51(1):22-33.

Abdulagatova Z, Abdulagatov IM, Emirov VN. Effect of temperature and pressure on the thermal conductivity of sandstone. Int J Rock Mech Min Sci. 2009;46(6):1055-71.

Aichholzer C, Duringer P, Orciani S, Genter A. New stratigraphic interpretation of the Soultz-sous-Forêts 30-year-old geothermal wells calibrated on the recent one from Rittershoffen (Upper Rhine Graben, France). Geotherm Energy. 2016;4(1):13.

Aichholzer C, Duringer Ph, Genter A. Detailed descriptions of the lower-middle Triassic and Permian formations using cores and gamma-rays from the EPS-1 exploration geothermal borehole (Soultz-sous-Forêts, Upper Rhine Graben, France). Geotherm Energy. 2019;7(1):34.

Albert K, Schulze M, Franz C, Koenigsdorff R, Zosseder K. Thermal conductivity estimation model considering the effect of water saturation explaining the heterogeneity of rock thermal conductivity. Geothermics. 2017;66:1-12.

Andrews-Speed C, Oxburgh ER, Cooper B. Temperatures and depth-dependent heat flow in western North Sea. AAPG Bulletin. 1984;68(11):1764-81.

Bächler D, Kohl T, Rybach L. Impact of graben-parallel faults on hydrothermal convection—Rhine Graben case study. Physics and Chemistry of the Earth, Parts A/B/C. 2003;28(9-11):431-41.

Baillieux P, Schill E, Edel J-B, Mauri G. Localization of temperature anomalies in the Upper Rhine Graben: insights from geophysics and neotectonic activity. Int Geol Rev. 2013;55(14):1744-62.

Baria R, Baumgärtner J, Gérard A, Jung R, Garnish J. European HDR research programme at Soultz-sous-Forêts (France) 1987-1996. Geothermics. 1999:28(4-5):655-69.

Bauer JF, Krumbholz M, Meier S, Tanner DC. Predictability of properties of a fractured geothermal reservoir: the opportunities and limitations of an outcrop analogue study. Geotherm Energy. 2017:5(1):24.

Baujard C, Genter A, Dalmais E, Maurer V, Hehn R, Rosillette R, et al. Hydrothermal characterization of wells GRT-1 and GRT-2 in Rittershoffen, France: implications on the understanding of natural flow systems in the rhine graben. Geothermics. 2017;1 (65):255-68.

Beardsmore GR, Cull JP, Cull JP. Crustal heat flow: a guide to measurement and modelling. Cambridge: Cambridge University Press; 2001.

Beck AE. Climatically perturbed temperature gradients and their effect on regional and continental heat-flow means. Tectonophysics. 1977;41(1):17-39.

Berger J-P, Reichenbacher B, Becker D, Grimm M, Grimm K, Picot L, et al. Eocene-Pliocene time scale and stratigraphy of the Upper Rhine Graben (URG) and the Swiss Molasse Basin (SMB). Int J Earth Sci. 2005;94(4):711-31.

Blackwell DD, Steele JL, Brott CA. The terrain effect on terrestrial heat flow. J Geophys Res. 1980;85(B9):4757-72.

Böcker J, Littke R. Thermal maturity and petroleum kitchen areas of Liassic Black Shales (Lower Jurassic) in the central Upper Rhine Graben, Germany. Int J Earth Sci. 2016;105(2):611-36.

Böcker J, Littke R, Forster A. An overview on source rocks and the petroleum system of the central Upper Rhine Graben. Int J Earth Sci. 2017;106(2):707-42.

Bücker C, Rybach L. A simple method to determine heat production from gamma-ray logs. Mar Pet Geol. 1996;13(4):373-5.

Bullard EC. The time necessary for a bore hole to attain temperature equilibrium. Geophys J Int. 1947;5:127-30.

Cermák V, Rybach L. Terrestrial heat flow in Europe. New York: Springer; 2012. ISBN 978-3-642-95357-6.

Chaki S, Takarli M, Agbodjan WP. Influence of thermal damage on physical properties of a granite rock: porosity, permeability and ultrasonic wave evolutions. Constr Build Mater. 2008;22(7):1456-61.

Clauser C, Huenges E. Thermal conductivity of rocks and minerals. In: Ahrens TJ, editor. AGU Reference Shelf. Washington, D. C.: American Geophysical Union; 1995. p. 105-26. http://www.agu.org/books/rf/v003/RF003p0105/RF003p0105 .shtml. Accessed 1 Jun 2018.

Clauser C, Villinger $\mathrm{H}$. Analysis of conductive and convective heat transfer in a sedimentary basin, demonstrated for the Rheingraben. Geophys J Int. 1990;100(3):393-414.

Dezayes C, Genter A, Hooijkaas GR. Deep-seated geology and fracture system of the EGS Soultz reservoir (France) based on recent $5 \mathrm{~km}$ depth boreholes. 2005.

Duringer P, Aichholzer C, Orciani S, Genter A. The complete lithostratigraphic section of the geothermal wells in Rittershoffen (Upper Rhine Graben, eastern France): a key for future geothermal wells. BSGF Earth Sci Bull. 2019;190:13. https://doi.org/10.1051/bsgf/2019012.

Earnest C. Thermal analysis of selected illite and smectite clay minerals. Part I. Illite clay specimens Thermal analysis in the geosciences. New York: Springer; 1991a. p. 270-86.

Earnest C. Thermal analysis of selected illite and smectite clay minerals. Part II. Smectite clay minerals Thermal analysis in the geosciences. New York: Springer; 1991b. p. 288-312.

England P, Oxburgh E, Richardson S. Heat refraction and heat production in and around granite plutons in north-east England. Geophys J Int. 1980;62(2):439-55. 
Équipe du projet GeORG. Potentiel géologique profond du Fossé rhénan supérieur. Rapport scientifique et technique du projet Interreg GeORG, Part 1-4. 2013. http://www.geopotenziale.eu.

Flores Marquez EL. Transferts de chaleur et de masse en milieu sédimentaire et fracture : modélisation numérique de la convection naturelle autour du site géothermique de Soultz (Graben du Rhin) [PhD Thesis]. 1992. http:// www.theses.fr/1992INPL048N/document.

Frone Z, Blackwell D, Richards M, Hornbach M. Heat flow and thermal modeling of the Appalachian Basin, West Virginia. Geosphere. 2015;11(5):1279-90.

Fuchs $\mathrm{S}$. The variability of rock thermal properties in sedimentary basins and the impact on temperature modelling —a Danish example. Geothermics. 2018;76:1-14.

Fuchs S, Balling N. Improving the temperature predictions of subsurface thermal models by using high-quality input data. Part 1: uncertainty analysis of the thermal-conductivity parameterization. Geothermics. 2016;64:42-54.

Fuchs S, Schütz F, Förster H-J, Förster A. Evaluation of common mixing models for calculating bulk thermal conductivity of sedimentary rocks: correction charts and new conversion equations. Geothermics. 2013;47:40-52.

Fulton PM, Saffer DM. Effect of thermal refraction on heat flow near the San Andreas Fault, Parkfield, California. Journal of Geophysical Research: Solid Earth. 2009;114(B6).

Gable R. Température, gradient et flux de chaleur terrestre: mesures, interprétation. Orléans: Editions du Bureau de recherches géologiques et minières, Service géologique national; 1986.

Garibaldi C. Determination des températures profondes du Bassin du Sud-Est de la France et relations entre anomalies thermiques, géologie et circulations hydrothermales par modélisation 3D. Sciences de la Terre. Université Nice Sophia Antipolis; 2010. https://tel.archives-ouvertes.fr/tel-00493961.

Genter A, Traineau H. Borehole EPS-1, Alsace, France: preliminary geological results from granite core analyses for Hot Dry Rock research. Sci Drill. 1992;3(5):205-14.

Genter A, Evans K, Cuenot N, Fritsch D, Sanjuan B. Contribution of the exploration of deep crystalline fractured reservoir of Soultz to the knowledge of enhanced geothermal systems (EGS). CR Geosci. 2010;342(7-8):502-16.

Genter A, Vidal J, Baujard C, Dalmais E, Schmittbuhl J. Permeability in deep-seated granitic rocks: lessons learnt from deep geothermal boreholes in the Upper Rhine Graben. 2015. p. 8.

Gérard A, Genter A, KohI T, Lutz P, Rose P, Rummel F. The deep EGS (Enhanced Geothermal System) project at Soultzsous-Forêts (Alsace, France). Geothermics. 2006;35(5-6):473-83.

Griffiths L, Heap MJ, Wang F, Daval D, Gilg HA, Baud P, et al. Geothermal implications for fracture-filling hydrothermal precipitation. Geothermics. 2016;64:235-45.

Griffiths L, Lengliné O, Heap M, Baud P, Schmittbuhl J. Thermal cracking in Westerly Granite monitored using direct wave velocity, coda wave interferometry, and acoustic emissions. J Geophys Res. 2018;123(3):2246-61.

Guéquen Y, Palciauskas V. Introduction à la physique des roches. Paris: Hermann; 1992.

Guillou-Frottier L, Carre C, Bourgine B, Bouchot V, Genter A. Structure of hydrothermal convection in the Upper Rhine Graben as inferred from corrected temperature data and basin-scale numerical models. J Volcanol Geoth Res. 2013;256:29-49.

Guillou-Frottier L, Jaupart C, Mareschal J, Gariépy C, Bienfait G, Cheng L-Z, et al. High heat flow in the Trans-Hudson Orogen, central Canadian Shield. Geophys Res Lett. 1996;23(21):3027-30.

Guillou-Frottier L, Lucazeau F, Garibaldi C, Bonte D, Couëffe R. Heat flow and deep temperatures in the Southeast Basin of France: implications for local rheological contrasts. Bulletin de la Société Géologique de France. 2010;181(6):531-46.

Guillou-Frottier L, Mareschal J, Musset J. Ground surface temperature history in central Canada inferred from 10 selected borehole temperature profiles. J Geophys Res. 1998;103(B4):7385-97.

Guo PY, Zhang N, He MC, Bai BH. Effect of water saturation and temperature in the range of 193 to $373 \mathrm{~K}$ on the thermal conductivity of sandstone. Tectonophysics. 2017;699:121-8.

Gustafsson SE. Transient plane source techniques for thermal conductivity and thermal diffusivity measurements of solid materials. Rev Sci Instrum. 1991;62(3):797-804.

Gustavsson M, Gustafsson SE. On the use of transient plane source sensors for studying materials with direction dependent properties. Thermal Conductivity 26: Thermal Expansion 14: Joint Conferences, August 6-8, 2001, Cambridge; DEStech Publications, Inc; 2005. p. 367.

Haffen S. Caractéristiques géothermiques du réservoir gréseux du Buntsandstein d'Alsace. 2012. http://www.these s.fr/2012STRAH004/document.

Haffen S, Géraud Y, Diraison M, Dezayes C. Determination of fluid-flow zones in a geothermal sandstone reservoir using thermal conductivity and temperature logs. Geothermics. 2013;46:32-41.

Haffen S, Géraud Y, Rosener M, Diraison M. Thermal conductivity and porosity maps for different materials: a combined case study of granite and sandstone. Geothermics. 2017;66:143-50.

Harcouët V. Modélisations thermiques de gisements orogéniques mésothermaux: application au Ghana. Géophysique [physics.geo-ph]. Institut de physique du globe de paris-IPGP, 2005. Français.

Heap MJ, Kushnir ARL, Gilg HA, Wadsworth FB, Reuschlé T, Baud P. Microstructural and petrophysical properties of the Permo-Triassic sandstones (Buntsandstein) from the Soultz-sous-Forêts geothermal site (France). Geothermal Energy. 2017. https://doi.org/10.1186/s40517-017-0085-9.

Heap MJ, Reuschlé T, Kushnir AR, Baud P. The influence of hydrothermal brine on the short-term strength and elastic modulus of sandstones from exploration well EPS-1 at Soultz-sous-Forêts (France). Geothermal Energy. 2018;6(1):29.

Heap MJ, Villeneuve M, Kushnir ARL, Farquharson JI, Baud P, Reuschlé T. Rock mass strength and elastic modulus of the Buntsandstein: an important lithostratigraphic unit for geothermal exploitation in the Upper Rhine Graben. Geothermics. 2019;77:236-56.

Hinsken S, Schmalholz SM, Ziegler PA, Wetzel A. Thermo-Tectono-Stratigraphic Forward Modelling of the Upper Rhine Graben in reference to geometric balancing: brittle crustal extension on a highly viscous mantle. Tectonophysics. 2011;509(1-2):1-13. 
Hinsken S, Ustaszewski K, Wetzel A. Graben width controlling syn-rift sedimentation: the Palaeogene southern Upper Rhine Graben as an example. Int J Earth Sci. 2007;96(6):979-1002.

Jaeger JC, Sass JH. Lees's topographic correction in heat flow and the geothermal flux in Tasmania. Geofisica Pura e Applicata. 1963;54(1):53-63.

Kadoya K, Matsunaga N, Nagashima A. Viscosity and thermal conductivity of dry air in the gaseous phase. J Phys Chem Ref Data. 1985;14(4):947-70.

Kant MA, Ammann J, Rossi E, Madonna C, Höser D, von Rohr PR. Thermal properties of Central Aare granite for temperatures up to $500^{\circ} \mathrm{C}$ : irreversible changes due to thermal crack formation. Geophys Res Lett. 2017;44(2):771-6.

Kappelmeyer O. European HDR project at Soultz-sous-Forêts general presentation. Geotherm Sci Tech. 1991;2(4):263-89.

Kohl T, Bächler D, Rybach L. Steps towards a comprehensive thermo-hydraulic analysis of the HDR test site soultz-sousforêts. 2000.

Kushnir AR, Heap MJ, Baud P. Assessing the role of fractures on the permeability of the Permo-Triassic sandstones at the Soultz-sous-Forêts (France) geothermal site. Geothermics. 2018;74:181-9.

Le Carlier C, Royer J-J, Flores EL. Convective heat transfer at the Soultz-sous-Forets Geothermal Site: implications for oil potential. First Break. 1994;12(11):553-60.

Lee T-C, Henyey TL. Heat-flow refraction across dissimilar media. Geophys J Int. 1974;39(2):319-33.

Lucazeau F. Analysis and mapping of an updated terrestrial heat flow data set. Geochem Geophys Geosyst. 2019;20(8):4001-24.

Lucazeau F, Vasseur G. Heat flow density data from France and surrounding margins. Tectonophysics. 1989;164(2):251-8.

Luijendijk E, ter Voorde M, van Balen R, Verweij H, Simmelink E. Thermal state of the Roer Valley Graben, part of the European Cenozoic Rift System: thermal state of the Roer Valley Graben. Basin Res. 2011;23(1):65-82.

Magnenet V, Fond C, Genter A, Schmittbuhl J. Two-dimensional THM modelling of the large scale natural hydrothermal circulation at Soultz-sous-Forêts. Geotherm Energy. 2014;2(1):17.

Majorowicz J, Wybraniec S. New terrestrial heat flow map of Europe after regional paleoclimatic correction application. Int J Earth Sci (Geol Rundsch). 2011;100(4):881-7.

Mareschal J-C, Jaupart C, Gariépy C, Cheng L-Z, Guillou-Frottier L, Bienfait G, et al. Heat flow and deep thermal structure near the southeastern edge of the Canadian Shield. Can J Earth Sci. 2000;37(2-3):399-414.

Ménillet F. Carte géologique de la France à 1/50 000198 Haguenau. 2e éd. Orléans: Bureau de recherches géologiques et minières; 2015.

Mielke P, Bär K, Sass I. Determining the relationship of thermal conductivity and compressional wave velocity of common rock types as a basis for reservoir characterization. J Appl Geophys. 2017;1 (140):135-44

Mollo S, Vinciguerra S, lezzi G, larocci A, Scarlato P, Heap MJ, et al. Volcanic edifice weakening via devolatilization reactions. Geophys J Int. 2011;186(3):1073-7.

Nagaraju P, Roy S. Effect of water saturation on rock thermal conductivity measurements. Tectonophysics. 2014:626:137-43.

Place J, Diraison M, Naville C, Géraud Y, Schaming M, Dezayes C. Decoupling of deformation in the Upper Rhine Graben sediments Seismic reflection and diffraction on 3-component Vertical Seismic Profiling (Soultz-sous-Forêts area). CR Geosci. 2010;342(8):575-86.

Popov Y, Tertychnyi V, Romushkevich R, Korobkov D, Pohl J. Interrelations between thermal conductivity and other physical properties of rocks: experimental data. In: Kümpel HJ, editor. Thermo-hydro-mechanical coupling in fractured Rock. Basel: Birkhäuser; 2003. https://doi.org/10.1007/978-3-0348-8083-1_21.

Pribnow D, Clauser C. Heat and fluid flow at the soultz hot dry rock system in the rhine graben. Kyushu-Tohoku: Japan; 2000. p. 6.

Pribnow D, Schellschmidt R. Thermal tracking of upper crustal fluid flow in the Rhine graben. Geophys Res Lett. 2000;27(13):1957-60.

Roussé $\mathrm{S}$. Architecture et dynamique des séries marines et continentales de l'oligocène moyen et supérieur du sud du fossé rhénan: Evolution des milieux de dépôt en contexte de rift en marge de l'avant-pays alpin. 2006.

Rybach L. The geothermal conditions in the Rhine Graben-a summary. Bulletin für Angewandte Geologie. 2007;12(1):29-32.

Sadeghiamirshahidi M, Vitton SJ. Analysis of drying and saturating natural gypsum samples for mechanical testing. J Rock Mech Geotech Eng. 2019;11(2):219-27.

Schellschmidt R, Clauser C. The thermal regime of the Upper Rhine Graben and the anomaly at Soultz. Z Angew Geol. 1996:42(1):40-4

Schellschmidt R, Schulz R. Hydrogeothermic studies in the hot dry rock project at Soultz-sous-Forets. Geotherm Sci Technol. 1992;1:217-38.

Schön JH, Dasgupta A. Physical properties of rocks: fundamentals and principles of petrophysics. 2nd ed. Amsterdam: Elsevier; 2015.

Schütz F, Förster H-J, Förster A. Thermal conditions of the central Sinai Microplate inferred from new surface heat-flow values and continuous borehole temperature logging in central and southern Israel. J Geodyn. 2014;76:8-24.

Schütz F, Norden B, Förster DESIRE Group A. Thermal properties of sediments in southern Israel: a comprehensive data set for heat flow and geothermal energy studies. Basin Res. 2012;24(3):357-76.

Serra O, Serra L. Diagraphies: acquisition et applications. Hérouville: Serralog; 2000.

Sissingh W. Comparative tertiary stratigraphy of the Rhine Graben, Bresse Graben and Molasse Basin: correlation of Alpine foreland events. Tectonophysics. 1998;300(1-4):249-84.

Sittler C. Le Paléogène des fossés rhénan et rhodanien, études sédimentologiques et paléoclimatiques: par Claude Sittler,... Service de la carte géologique d'Alsace et de Lorraine; 1965.

Sittler C. Illustration de I'histoire géologique du Fossé rhénan et de I'Alsace. N Jb Geol Palaont Abh. 1992;186(3):255-82.

Surma F, Geraud Y. Porosity and thermal conductivity of the Soultz-sous-Forêts granite. Pure Appl Geophys. 2003;160(5):1125-36.

Vasseur G. A critical study of heat flow data in France. In: Strub AS, Ungemach P, editors. Advances in European Geothermal Research. Springer: Netherlands; 1980. p. 474-84. 
Vasseur G. Synthèse des résultats de flux géothermique en France. Ann Geophys. 1982;38(2):189-201.

Vidal J, Genter A. Overview of naturally permeable fractured reservoirs in the central and southern Upper Rhine Graben: insights from geothermal wells. Geothermics. 2018;74:57-73.

Vidal J, Genter A, Schmittbuhl J. How do permeable fractures in the Triassic sediments of Northern Alsace characterize the top of hydrothermal convective cells? Evidence from Soultz geothermal boreholes (France). Geotherm Energy 2015;3(1):8.

Vosteen H-D, Schellschmidt R. Influence of temperature on thermal conductivity, thermal capacity and thermal diffusivity for different types of rock. Phys Chem Earth. 2003;28(9-11):499-509.

Walsh JB, Decker ER. Effect of pressure and saturating fluid on the thermal conductivity of compact rock. J Geophys Res. 1966;71(12):3053-61.

Wang J-Y, Wang J-A, Xiong L-P, Zhang J-M. Analysis of factors affecting heat flow density determination in the Liaohe Basin, North China. Tectonophysics. 1985;121(1):63-78.

Waples DW. A new model for heat flow in extensional basins: estimating radiogenic heat production. Nat Resourc Res. 2002;9:227-38.

Woodside W, Messmer JH. Thermal conductivity of porous media I unconsolidated sands. J Appl Phys. 1961;32(9):1688-99.

Zimmerman RW. Thermal conductivity of fluid-saturated rocks. J Petrol Sci Eng. 1989;3(3):219-27.

\section{Publisher's Note}

Springer Nature remains neutral with regard to jurisdictional claims in published maps and institutional affiliations.

\section{Submit your manuscript to a SpringerOpen ${ }^{\circ}$} journal and benefit from:

- Convenient online submission

- Rigorous peer review

- Open access: articles freely available online

- High visibility within the field

Retaining the copyright to your article

Submit your next manuscript at $\gg$ springeropen.com 